\title{
Morphological variation of fine root systems and leaves in primary and secondary tropical forests of Hainan Island, China
}

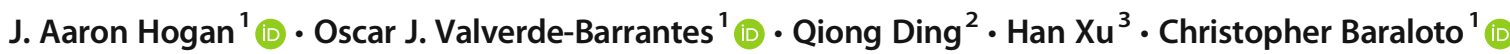

Received: 10 January 2020 / Accepted: 22 June 2020 / Published online: 13 August 2020

(C) INRAE and Springer-Verlag France SAS, part of Springer Nature 2020

\begin{abstract}
- Key message In older, unlogged rainforest of Hainan Island, China, leaves of saplings were larger, and fine root systems of saplings were thicker with fewer root tips than in historically logged areas. These results were consistent among 15 Angiosperm lineages, even though families differed widely in their leaf and root traits.

- Context How plant organ morphologies vary with environment is key for inferring plant functional strategies.

- Aims We were interested in quantifying any changes in fine root and leaf morphology of saplings with local-scale environmental variation in tropical forest, and if any variation in organ morphologies differed with plant lineage.

- Methods We measured functional traits of fine root systems and leaves of saplings from 15 families in historically logged and unlogged Chinese tropical forest, where soil fertility and texture slightly decreased with greater forest age.

- Results Root morphological traits were more conservative, while leaf morphologies were more acquisitive in primary forest than in secondary forest. From secondary to primary forests, mean root system diameter increased $0.4 \mathrm{~mm}$, mean specific root length decreased $3.5 \mathrm{~m} \mathrm{~kg}^{-1}$, and mean root system branching intensity decreased by 0.3 tips $\mathrm{cm}^{-1}$. Similarly, from secondary to primary forests, average leaf area increased $7 \mathrm{~cm}^{2}$ and specific leaf area decreased $0.8 \mathrm{~m}^{2} \mathrm{~kg}^{-1}$. Leaf thickness and root tissue density were not different. Among the selected plant families, root and leaf morphological differences between forest types were consistent.

- Conclusion Within lineage (i.e., intraspecific) root and leaf morphological variation showed contrasting patterns. Local-scale variation in soil phosphorus and base saturation affected intraspecific variation in root diameter and specific root length.
\end{abstract}

Keywords Plant functional traits $\cdot$ Trait variation $\cdot$ Root morphology $\cdot$ Leaf morphology $\cdot$ Tropical forest $\cdot$ Jianfengling $\cdot$ Hainan Island

Handling Editor: Andreas Bolte

Contributions of the co-authors

Conceptualization: JAH, OJV-B, CB; Methodology: JAH, OJV-B, QD; Software: NA; Validation: JAH; Formal analysis: JAH; Investigation: JAH; Resources: JAH, CB, QD, XH; Data Curation: JAH; Writing — original draft: JAH; Writing — review and editing: JAH,OJVB, QD, XH, CB ; Visualization: JAH; Supervision: CD, XH; Project administration: JAH; Funding acquisition: JAH

J. Aaron Hogan

jhogan@fiu.edu

Oscar J. Valverde-Barrantes

ovalverde@fiu.edu

Qiong Ding

dingqiong@hainu.edu.cn

$\mathrm{Han} \mathrm{Xu}$

ywfj@163.com
Christopher Baraloto

cbaralot@fiu.edu

1 Department of Biological Sciences, International Center for Tropical Botany, Florida International University, Miami, FL 33199, USA

2 Research Center for Terrestrial Biodiversity of the South China Sea, Institute of Tropical Agriculture and Forestry, Hainan University, Haikou 570228, China

3 Research Institute of Tropical Forestry, Chinese Academy of Forestry, Longdong, Guangzhou 510520, China 


\section{Introduction}

Comparative ecology with plant traits has been a popular approach to understand trade-offs in plant form, physiology, and biological functioning, which generally scale with variation in plant ecological life-history (Keddy 1992; Weiher et al. 1999; Westoby and Wright 2006; Shipley et al. 2016; Körner 2018). Functional traits, such as specific leaf area (SLA; Garnier et al. 2001) or wood density (Chave et al. 2009), inform about resource allocation within the plant in relation to a fast- or slowgrowth strategy (Wright et al. 2010; Reich 2014), total photosynthetic potential (Shipley 1995), or other measures of the relative performance across plant species (Weiher et al. 1999; Ackerly et al. 2002; Díaz et al. 2016). Interspecific trade-offs in resource allocation concerning the most-commonly measured functional traits have been observed along at least two orthogonal axes of variation (Díaz et al. 2016): one encompassing stem economics (Baraloto et al. 2010) related to whole plant size (King 1996) and another related to the leaf economics spectrum (Wright et al. 2004).

Functional trait measurement of fine roots is a relatively recent development in plant functional ecology (Bardgett et al. 2014; Laliberté 2017; Iversen et al. 2017). The emerging hypothesis for variation in root functional traits among plant species is that low specific root length (SRL), thick root diameter, high C:N ratios in tissues, and high root tissue density should relate to low nutrient uptake capacities, low rates of root respiration, and long root lifespans and are thus considered conservative root traits (Fig. 1). In applying plant economic theory (Bloom et al. 1985; Reich 2014) to roots, such conservative root traits should reflect a slow-growth plant strategy (Reich 2014; Weemstra et al. 2016), although a consensus is currently lacking. In contrast, thin root diameters, high SRL, high root tissue $\mathrm{N}$ content, and low root tissue densities should relate to higher rates of root respiration, fast rates of root turnover, and should be acquisitive traits indicative of a fast-growth plant strategy (Fig. 1). Root tissue density and diameter are positively related to root lifespan and drought resistance but negatively related to nutrient uptake potential (Kramer-Walter et al. 2016; Valverde-Barrantes and Blackwood 2016). Accordingly, root diameter and tissue density should increase among species with a fastgrowth to a slower-growth strategy, while SRL, root area, and root tip abundance should decrease (Weemstra et al. 2016; McCormack et al. 2012; Fig. 1).

Plant evolutionary history strongly constrains root morphologies. Across taxa, the general pattern is that gymnosperms and basal angiosperms (e.g., Magnoliids) have thicker, less-dense, shorter roots, with fewer fine root tips than more derived angiosperms (Kong et al. 2014; Valverde-Barrantes et al. 2016; Wang et al. 2019). This may signify a greater reliance on mycorrhizal associations for nutrient acquisition

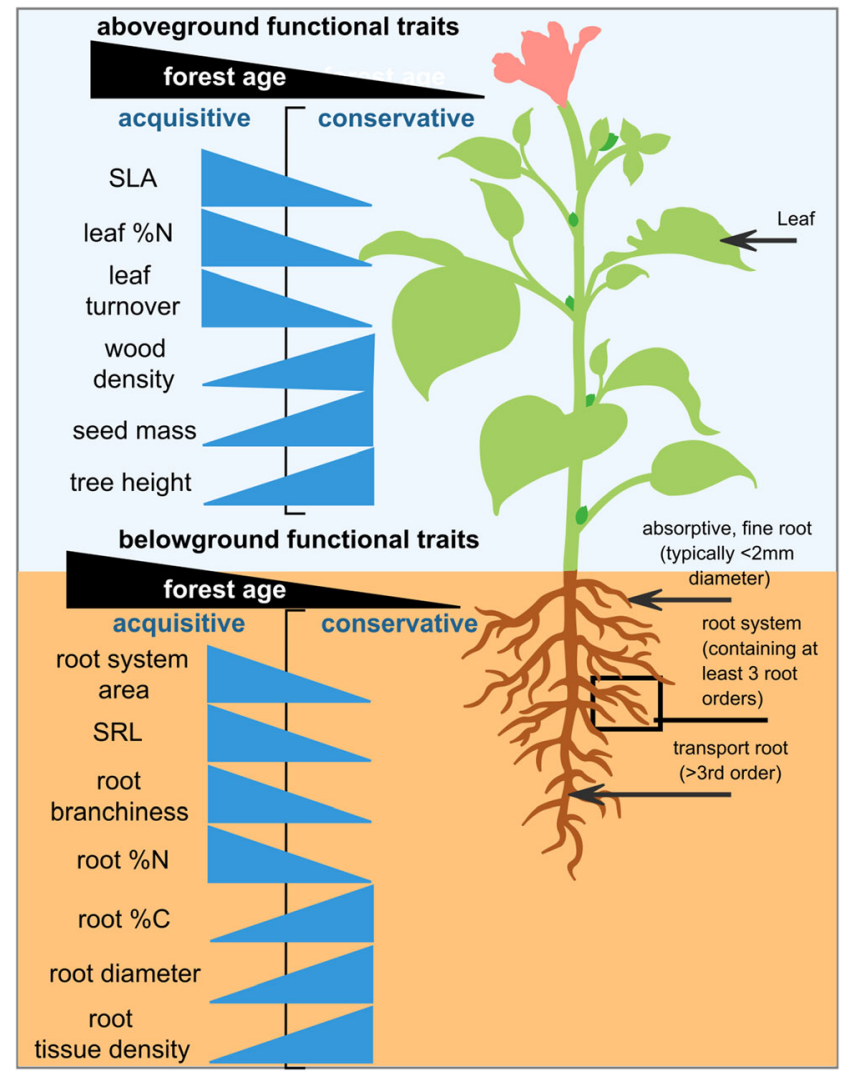

Fig. 1 Conceptual diagram of commonly measured aboveground and belowground functional traits along an acquisitive-conservative life-history continuum (i.e., fast-slow plant spectrum; Reich 2014). Hypotheses for how within-species (i.e., intraspecific) variation in root and leaf morphologies should relate to increasing forest age (i.e., forest succession) are shown in black (see research question 1)

(Eissenstat et al. 2015; Chen et al. 2016; Valverde-Barrantes et al. 2016; Kong et al. 2017), or it may be a result of divergent evolutionary processes that have created a high degree of phylogenetic conservatism in Angiosperm root diameter (Ma et al. 2018; Lu and Hedin 2019). Thus, because of the systematic variation in root diameter, studies investigating intraspecific variation in root morphologies in relation to the environment should account for plant lineage. Demonstratively, using family-level data from 581 species from 22 plant orders (Valverde-Barrantes et al. 2017), Maherali (2017) showed that the standard deviation of root diameter increased with the average root diameter. Yet, there was substantial variation among families, and therefore, it remains uncertain how intraspecific variation in root morphology due to environment scales with root diameter, plant lineage, or plant strategy. A large proportion of the variation in root morphologies can be explained by continental-scale climate variation (Jackson et al. 1996; Freschet et al. 2017; Wang et al. 2019), yet some variation remains unaccounted for (Freschet and Roumet 2017; Valverde-Barrantes et al. 2017). For example, specific root length and root tissue density of Gymnosperm roots decrease with increasing latitude in boreal forests; that is, roots show an 
intraspecific conservative shift with decreasing temperature and increasing soil fertility (Zadworny et al. 2016; Defrenne et al. 2019). In addition, a more-general community shift in root acquisitiveness occurs toward the tropics as Angiosperms dominate over Gymnosperms (Wang et al. 2018; Wang et al. 2019).

Root morphology also varies with the local soil environment. At the individual plant scale, variation in root traits can be large; for example, interspecific variation in root diameter, specific root length (SRL), and link length within a community can be twenty-fold (Comas and Eissenstat 2009; Guo et al. 2008). Such variation has potentially large ramifications for the ecologies of plant species (Schenk and Jackson 2002; Craine et al. 2001; Comas and Eissenstat 2009; Van Kleunen et al. 2010; Bardgett et al. 2014; Wang et al. 2018), including nutrient acquisition and use strategies (Warren et al. 2015) and how species respond to selection pressures (e.g., altered soil fertility, land-use change, or forest recovery). Despite interspecific differences in root diameter, plants have been shown to modulate root architecture in response to cues in the soil environment (i.e., soil moisture and fertility; Fitter and Stickland 1991; López-Bucio et al. 2003; Hodge et al. 2009). Nutrient deficiencies in the soil usually lead to the lengthening and architectural development of root systems, for example, a more pronounced herringbone topology, with more root branching and longer lengths originating from a single main root (Fitter and Stickland 1991; López-Bucio et al. 2003; Giehl et al. 2013). Thus, understanding interspecific and intraspecific variations in root morphologies with soil conditions may help quantify the relative role of belowground specialization versus local adaptation among plant lineages.

Leaf morphologies of plants are as less phylogenetically constrained than those of roots (Kembel and Cahill Jr 2011; Flores et al. 2014), indicating an independence in drivers of among and within species variation in leaf versus root functional traits (Wang et al. 2017). Like roots, climate strongly influences leaf morphology at the continental scale (Wright et al. 2017). At the local scale, light availability is the primary driver of leaf morphology, with leaves tending to become more acquisitive in more shaded environments. For example, leaves of the same species increase in SLA as light becomes increasingly limited (Liu et al. 2016). The increase in SLA is mainly driven by an increase in leaf area, in response to increasing forest canopy coverage and competition for light (Givnish 1984; Rijkers et al. 2000; Keenan and Niinemets 2017). Yet, despite the relatively subtle shifts in leaf morphologies that occur in response to the light environment, large interspecific differences in leaf morphologies exist among taxa (Wright et al. 2004, 2010, 2017). Thus, understanding how interspecific and intraspecific variations in leaf morphology interact with the understory forest light environment (i.e., forest structure and successional status) is important to interpret how environments shape functional traitenvironment relationships of plants. Additionally, some evidence shows that among species leaf and root morphologies are related (i.e., SRL increases with increasing SLA; Valverde-Barrantes et al. 2017), however the degree to which intraspecific variation in root systems coordinates with variation in leaves, and how variation relates to the soil environment is not completely understood. Notably, one study found that among Neotropical trees, coarse woody root traits were more aligned with stem than leaf functional traits and that relationships were consistent across different soil habitats present in the Amazon (Fortunel et al. 2012).

Generally, root biomass and competition for soil nutrients increase with forest succession, which drives shifts in the amount and form of available nutrient pools in the soil (Christensen and Peet, 1984; Hertel et al. 2003; Craine; 2006). One might hypothesize that roots of the same species should become more acquisitive (i.e., an intraspecific shift toward acquisitive root functional traits like an increase in root length; see Fig. 1), as soil fertility changes with succession (e.g., shifts from nitrate to ammonium dominated nitrogen cycling and cation and base saturation decreases; Werner 1984). However, several studies have documented intraspecific conservative shifts in root morphologies as soil fertility decreases (Eissenstat et al. 2000; Holdaway et al. 2011; Li et al. 2018). Only a few studies have examined how root morphologies vary with forest age in tropical forest (see Hopkins et al. 1996; Hertel et al. 2003; Leuschner et al. 2009; Zangaro et al. 2012; Powers and Peréz-Aviles 2013). Those that have focused on root morphologies in tropical forest have found that root biomass increases, root turnover decreases, and generally roots become less acquisitive (e.g., decrease in root length and number of root tips) with increasing successional status (Hertel et al. 2003; Leuschner et al. 2009). However, differences in methodology exist because all of these studies use soil coring methods, which limits their ability to directly assess intraspecific variation in root morphologies. Additionally, competition for light generally increases with forest succession. Morphological plasticity in leaf morphologies in response to light availability illustrates intraspecific trait variation with environment. Plant root systems must simultaneously forage for 14 mineral elements from the soil in addition to absorbing water (Lynch 2005; Warren et al. 2015), whereas leaves principally respond to light availability. Thus, it is not unreasonable to hypothesize that morphological plasticity of root systems could be more pronounced and multidimensional than that of leaves, due to the more complex nature of soil resource acquisition compared with light interception (Fitter 1991; Weemstra et al. 2016; Maherali 2017; Laliberté 2017).

In that context, our two research questions and accompanying hypotheses were as follows: 
1 How does functional trait variation in leaves and fine root systems relate to local-scale environmental variation in soil fertility and texture attributable to topical montane forest successional status? We hypothesized that intraspecific morphologies in understory leaves should become more acquisitive (e.g., increase SLA) as light availability decreases from secondary to primary forest. We hypothesized that roots of the same species would also become more acquisitive (e.g., increase in SRL, diameter) from secondary to primary forests. Incorporated in these two independent hypotheses is the idea that individual plants coordinate leaf and root traits to become more acquisitive with increasing forest age (Fig. 1).

2 Is morphological variation in root and leaf morphologies consistent across plant lineages? The testable null hypothesis, here, is that plant organ morphology-environment relationships do vary across lineages, so we hypothesized that intraspecific trait variation with environment would be consistent across taxa.

To test these hypotheses, we employed a paired sampling design that measured root and leaf morphological traits and soil chemistry within fifteen families, along a $6.6-\mathrm{km}$ transect in a tropical forest in southern China.

\section{Material and methods}

\subsection{Study site: Jianfengling, Hainan Island, China}

The Jianfengling forest reserve (JFL), of south-western Hainan island, China $\left(18^{\circ} 23^{\prime}-18^{\circ} 15^{\prime} \mathrm{N}\right.$ and $108^{\circ} 36^{\prime}-109^{\circ}$ $05^{\prime}$ E; Figs. 2 and 6) is a 47,200-ha area of mountainous tropical forest with a history of logging and forest resource extraction. Beginning in 1957, about two-thirds of the area was either clear-cut or selectively logged, meaning 30-40\% of large timber-valuable trees were extracted (Zhou 1995; Xu et al. 2015). All logging ceased in 1994 under a state-wide (Hainan island only) logging ban, followed by a Chinese national logging ban in 1998 (Zhou 1995; Wenhua 2004). The reserve encompasses several ecological life zones of vegetation, from tropical semi-deciduous monsoon forest at the lower elevations to mossy high elevation forest, with evergreenmonsoon forest dominated by Podocarpaceae intermixed throughout at elevations $<1000 \mathrm{~m}$ (Huang et al. 1995). The most common vegetation life zone is tropical montane rain forest, which occurs at elevations between 600 and $1100 \mathrm{~m}$. This forest is characterized by a mix of palms (principally Livistona saribus (Lour.) Merr. ex A. Chev.) and broadleaf evergreen trees that reach an average canopy of height of $18 \mathrm{~m}$ (Jin et al. 2013).

The forest has a tropical monsoon climate with seasonal rainfall, where most of the rainfall occurs between May and
October (Zeng 1995). From 1965 to 1995 , the average annual rainfall in the montane rain forest of JFL averaged about $2700 \mathrm{~mm}$ (Wu 1995). The soils are classified as lateritic and humic yellow soils, being derived from porphyritic granite (Wu 1995). Such soils are characterized by surface accumulation of organic matter, slower rates of mineral and organic matter cycling than other tropical soils (e.g., latisols), intermediate rates of mineral leaching, some accumulation of Aluminum, and exchangeable base content of about $30 \mathrm{~mL} \mathrm{~kg}^{-1}$ of soil (Wu 1995).

\subsection{Field methods}

During the summer (May 4 to June 30) of 2017, roots and leaves of juvenile trees (individuals $>1 \mathrm{~m}$ in height but $<$ $10 \mathrm{~cm}$ diameter at breast height, hereafter saplings) of fifteen families were sampled along a 6.6-km transect within the JFL reserve (Figs. 2 and 6; Hogan et al. 2019). The transect was positioned to cover the transition from secondary to primary forests. The secondary forest area of the transect was extensively logged or cut over between 1964 and 1970, making the forest about 50 years old. The primary forest area has no recorded logging history or other anthropogenic land use and included areas of the Jianfengling permanent forest dynamics plot. Forest basal area in primary and secondary forests is roughly equal, averaging $40.5( \pm 0.2$, standard error) $\mathrm{m}^{2} \mathrm{ha}^{-1}$ in primary forest and $42.7( \pm 0.2) \mathrm{m}^{2} \mathrm{ha}^{-1}$ for secondary forest (Xu et al. 2015). A total of 423 individuals (198 in primary and 225 in secondary forest) of 72 species from the 15 focal families (Table 6 in the Appendix) were collected in a paired approach that sought to collect three individuals of each species in each half of the transect.

Lateral fine roots from the top $10 \mathrm{~cm}$ of soil were traced out from an identified individual and gently excavated. Excavation of living root systems from saplings was done carefully to preserve root networks to finest first-order roots, using hand trowels. Following root collection, ca. $1 \mathrm{~kg}$ of surface soil was collected from the excavated area where roots were collected. Healthy, entire leaves were manually cleaved off the plant at the base of petiole and collected. Leaves and roots were transported back to the lab in plastic bags for processing. Measurements of leaf morphologies were done immediately, and roots were placed in a refrigerator for storage until they could be processed.

\subsection{Functional trait measurements}

For three leaves of each sapling, leaf thickness was measured using a Vernier micrometer (Mitutoyo USA) precise to a thousandth of a millimeter. Leaves, including petioles, were scanned (single-sided scans) for leaf morphological measurements. 
Fig. 2 The study site: the Jianfengling Forest Reserve (JFL) of Hainan Island, China. Hainan Island is a small continental island off the south-eastern coast of China, shown in the red box of the inset map. The 47,200-ha JFL boundary is shown in red. The $6.6-\mathrm{km}$ transect of where functional traits of saplings were sampled is shown in black (see Fig. 6 for a topographic map and an elevational profile of the transect). The first half of the transect is in secondary forest with a history of logging with and estimated forest age of about 50 years, and the second half of the transect is in unlogged, primary forest

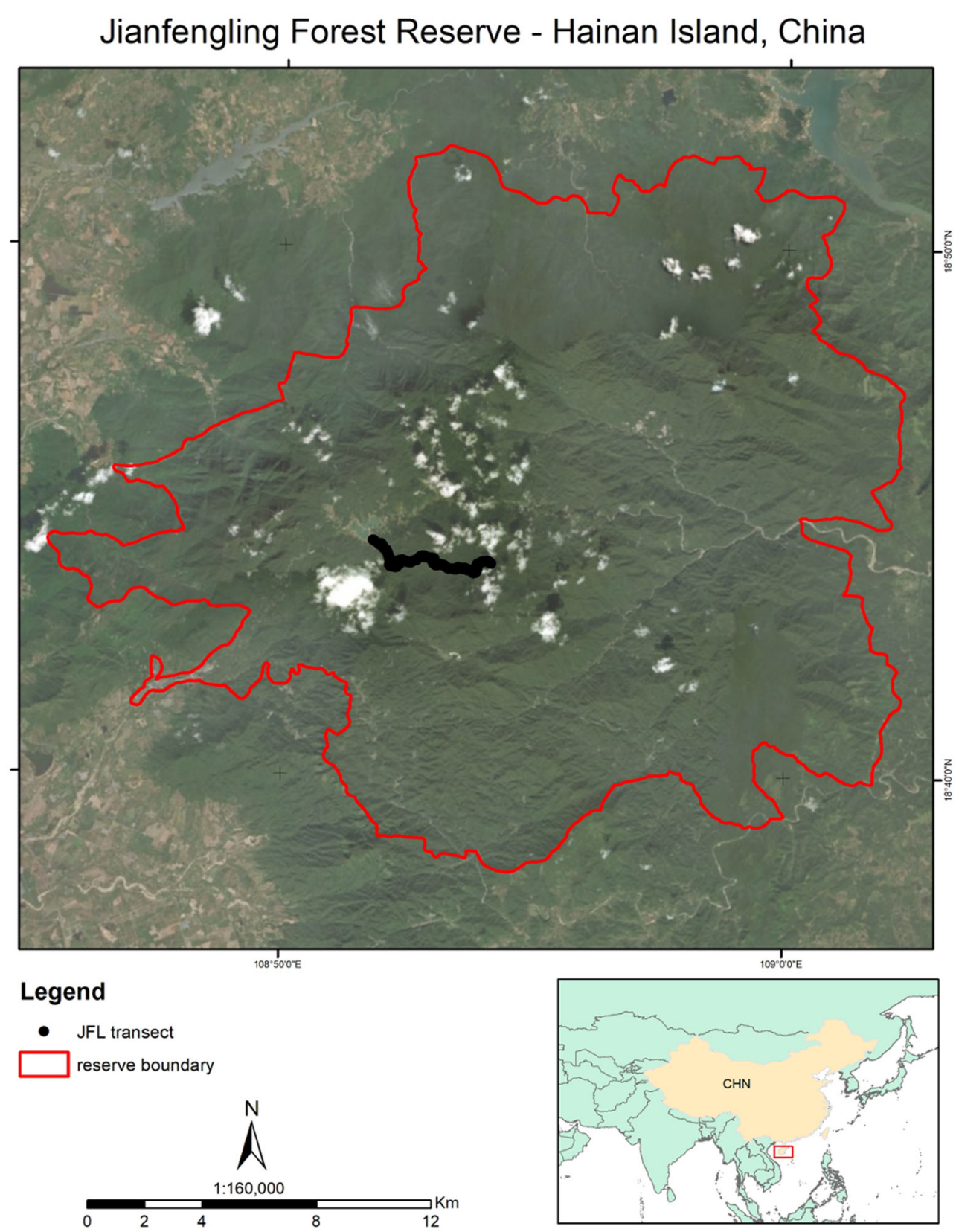

Prior to scanning, roots were washed thoroughly. For each individual, three to five root systems, containing at least the first 3 root orders (sensu McCormack et al. 2015) were selected from the excavated material. Roots were placed in an acrylic root scanning tray with a cover glass, submerged in water and scanned at high resolution (1200 dpi) in black and white using a double-sided optical scanner (Epson Perfection V800, Epson America, Inc.). Following scanning, leaves and roots were dried in an oven at $70{ }^{\circ} \mathrm{C}$ for at least $48 \mathrm{~h}$, before recording their dry mass.

Scanned images of leaves and roots were respectively analyzed using WinFolia (2007b version, Regent Instruments, Quebec, Canada) and WinRhizo (2016 version, Regent
Instruments, Quebec, Canada) software. WinFolia measures leaf area, height, width, perimeter, and aspect ratio. Specific leaf area (SLA) was calculated as the ratio of the surface area to the dry mass. WinRhizo measures root length, area, average diameter, volume, and architecture (i.e., the number of root tips and forks) for each root system. Specific root length (SRL), specific root surface area (SRA), and specific root tip abundance (SRTA) were calculated by dividing root length, root area, and the number of root tips for each root system, respectively, by its dry mass. Root branching intensity $(\mathrm{RBI})$ was calculated by dividing the number of root tips by the root system dry mass. Finally, root tissue density (RTD) was estimated by dividing root system volume by its dry mass. 


\subsection{Soil laboratory analyses}

Soils were analyzed for 300 of the 423 individuals collected (150 per forest type of 50 species, see Table 6 in the Appendix). Collected soil samples were air dried and sieved using at $2 \mathrm{~mm}$ mesh sieve. For each sample, about $300 \mathrm{~g}$ of soil was analyzed for soil texture and nutrient content. Soil $\mathrm{pH}$ was measured using a glass electrode in a 2.5:1 water to soil dilution. The high temperature, external-heat, potassium dichromate oxidation volumetric method was used to measure soil organic matter. The Kjieldahl-distillation titration method was used to measure soil total nitrogen $(\mathrm{N})$. Total phosphorus $(\mathrm{P})$, available potassium $(\mathrm{K})$, and exchangeable sodium, calcium, and magnesium were all measured using an ammonium-acetate extraction, followed by flame atomic absorption spectrophotometry. Total soil $\mathrm{K}$ was measured using sodium-hydroxide melting-flame atomic absorption spectrophotometry. Available (i.e. alkali-hydrolysable) soil N was measured using the alkali-solution diffusion method. Soil available $\mathrm{P}$ was measured using by the hydrochloric acidammonium fluoride extraction and the molybdenum antimony anti-coloring method. Lastly, soil base saturation (BS) and cation exchange capacity were measured with the ammonium acetate methods.

\subsection{Data analysis}

Principal components analyses (PCA) were carried out on root and leaf functional trait matrices to help reduce dataset dimensionality and identify relationships between leaf and root functional traits (see Figs. 7 and 8 in the Appendix). This was done separately for root and leaves, and in our case, we were interested in them separately. The traits used in the PCA for leaves were leaf area, leaf perimeter, leaf width, leaf height, leaf mass, SLA, and leaf thickness (see Table 4 in the Appendix). The traits used in the root PCA were root length, SRL, SRA, average diameter, RTD, RBI, and SRTA (see Table 5 in the Appendix). PCAs were successful in reducing the dimensionality of morphological trait data, with the first two axes of each PCA explaining $67 \%$ of the variability in the leaf trait data (Fig. 7 in the Appendix) and $72 \%$ of the variability in the root trait data (Fig. 8 in the Appendix). Leaf morphological traits were summarized by two main axes of variation (Table 4 in the Appendix): mass-based variation (SLA, dimension 2 in Fig. 7) and area-based variation (leaf area, dimension 1 in Fig. 7). Root morphological traits were not as orthogonally organized as leaf traits (Fig. 8; Table 5 in the Appendix). Therefore, based on trait correlation with PCA axes (Tables 4 and 5 in the Appendix), three leaf traits: leaf area, SLA, and leaf thickness, and four root traits: root system average diameter (hereafter root diameter), RTD, SRL, and RBI were chosen for subsequent analyses. We used trait values instead of PCA axis loadings in analyses to make our results easier to generalize with other studies.

Two-way, univariate analyses of variance (ANOVA) were conducted separately with each of the seven selected functional traits as the response variable. Functional trait values were $\log _{10}$ transformed as necessary to improve their normality, as was the case for leaf area and all four root traits. The two-way ANOVA models were fit in the form of: trait $\sim$ lineage $\times$ forest type. Forest type was represented in each model as two-level factor (i.e., primary vs secondary), and plant lineage was represented as species nested within plant family, which allowed us to assess intraspecific trait variation.

Stepwise ANOVA model selection was performed using all possible combinations of species lineage and forest type as factors. In all cases, the best-fitting models included the interaction between lineage and forest type. Those models were then used to predict the least-squares (i.e., marginal) mean trait values with respect to lineage and forest type (i.e., $\beta$ coefficients were used to estimate mean trait values and their confidence intervals for each lineage in both forest types). Analyses were carried out in R v.3.5.0 (R Core Team 2018) and made use of the "emmeans" package (Lenth 2018) for predicting the least square mean values. Effect sizes for predictors were calculated using the $\omega^{2}$ estimator via the "sjstats" package (Lüdecke 2019). We chose to use the $\omega^{2}$ effect size estimator, opposed to the $\eta^{2}$ (eta-squared) or $\eta_{p}^{2}$ (partial etasquared) estimators, because when predictor variable has many groups levels, $\eta^{2}$ and $\eta_{p}{ }^{2}$ can be biased, where $\omega^{2}$ is corrected for this bias (Lüdecke 2019). For interpretation of effect sizes, $\omega^{2}$ values near 0.01 are considered small, near 0.06 are considered medium, and near 0.14 are considered large.

In order to directly assess how variation in soils related to any variation in root traits because of forest type, we conducted analyses of covariance (ANCOVA). One-way ANCOVA models were conducted to determine if statistical differences existed between root functional traits and soil variables controlling for soil type. We used average root trait values for each individual (i.e., the average of the three to five root systems measured for each sapling) and soil data from the 300 individuals of 50 species where we measured soil properties (see Table 6 in the Appendix). ANCOVAs were done using the four root traits from the previous analyses: root diameter, SRL, RTD, and RBI and four soil variables of interest: soil BS, total N), total P, and total K. ANCOVA models were constructed similarly to the ANOVA models in the form: trait $\sim$ soil variable $*$ forest type $\times$ lineage, where like before, forest type was a two-level factor (i.e., primary vs secondary) and lineage was species nested within family. This is akin to conducting ordinary least-squares regression between soil variables and root trait values by forest type, which we did to graphically assess the direct influence of soil variation on root trait variation relationships.

\section{פ2 Springer INRAC}




\section{Results}

\subsection{Soil properties along the transect}

Soils in primary forest area of the transect were significantly more acidic and of coarser texture than soils from the secondary portion of the transect (Table 1). The range of soil nutrient contents was greater in secondary than in primary forest. Soils in the secondary forest portion of the transect were more fertile than those of the primary forest area, in that they measured significantly higher in total phosphorus, total potassium, available potassium, total exchangeable bases, effective cation exchange capacity, and base saturation. Soil organic matter, total nitrogen available nitrogen, and available phosphorus did not differ along the transect by forest type.

\subsection{Variation in leaf morphology along the transect}

Analysis of 1315 leaves and 1949 root systems from 423 individual saplings from 72 species showed significant interspecific trait variation. For example, predicted marginalmean SLA values varied from 8.1 ( \pm 0.6 , standard error) to $20.5( \pm 0.9) \mathrm{m}^{2} \mathrm{~kg}^{-1}$ for Sapindaceae and Sytracaceae, respectively (Fig. 3b). In the secondary forest portion of the transect, predicted marginal-mean SLA values for those two families increased to $9.3( \pm 0.3)$ and $21.7( \pm 1.0) \mathrm{m}^{2} \mathrm{~kg}^{-1}$. Differences in SLA by forest type were consistent with plant lineage, with SLA being on average $1.18 \mathrm{~m}^{2} \mathrm{~kg}^{-1}$ greater in secondary than in primary forest (Fig. 3b). Results were similar but inverse in directionality for leaf area (Fig. 3a), with predicted marginal-mean leaf area being $68.0( \pm 1.0)$ $\mathrm{cm}^{2}$ in secondary and $74.5( \pm 1.0) \mathrm{cm}^{2}$ in primary forest, a difference of about $6.5 \mathrm{~cm}^{2}$ that was largely consistent across plant families (Fig. 3b). No differences in leaf thickness were measured with respect to forest age (Fig. 3c; Table 2).

\subsection{Variation in fine root system morphology along the transect}

Root diameters for all root systems measured ranged from 0.3 to $3.3 \mathrm{~mm}$ and incorporated fine roots of the first three root orders. Root systems ranged in total root length from 9.4 to $415.67 \mathrm{~cm}$, averaging $97.5( \pm 1.4) \mathrm{cm}$. Regarding root morphology, the predicted-marginal mean difference in SRL was on average about $3.5 \mathrm{~m} \mathrm{~kg}^{-1}$ greater in secondary than in primary forest (Fig. 4b). For example, in the secondary forest, values ranged from $26.0( \pm 1.9) \mathrm{m} \mathrm{kg}^{-1}$ for species in the Annonaceae to $78.3( \pm 1.1)$ for the Juglandaceae. In the primary forest, values ranged from $23.8( \pm 1.1) \mathrm{m} \mathrm{kg}^{-1}$ for species in the Annonaceae to $71.9( \pm 1.1)$ for the Juglandaceae (Fig. 4b). Like the SLA and leaf area-relationship, root-system diameter had an opposite relationship to

\section{$\stackrel{Ð}{\equiv}$}



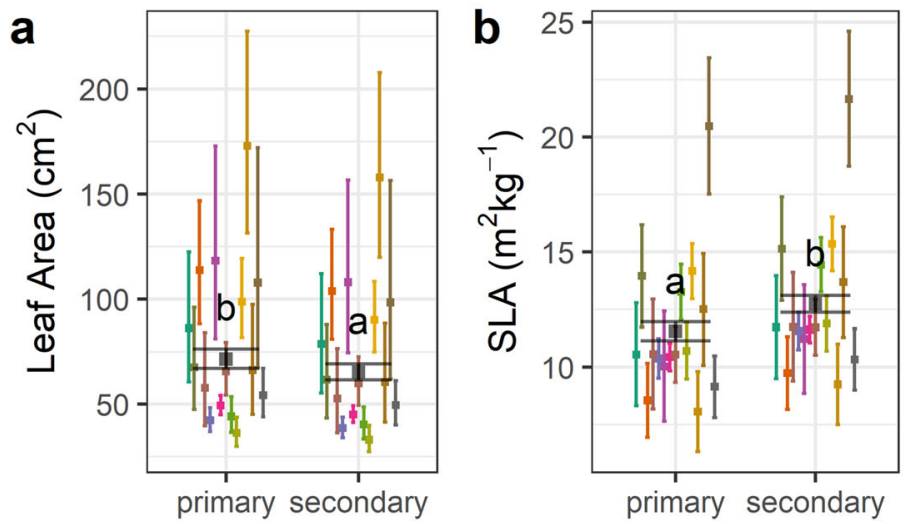

Fig. 3 Least-squares mean (points) with 95\% confidence intervals (vertical bars) for three morphological leaf traits. Leaf area (a), specific leaf area (SLA) (b), and leaf thickness (c) by forest type and plant family using data from 423 individuals from 72 species sampled along a 6.6$\mathrm{km}$ transect from secondary to primary forests. Values were predicted from linear models fit to field data in the form of trait $\sim$ forest type $\times$

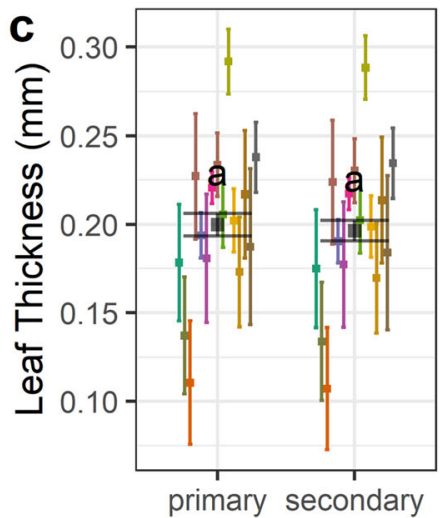

Family \# individuals(\# species)

- Anacardiaceae 6(1)

- Annonaceae 6(1)

- Burseraceae 6(1)

$\rightarrow$ Ebenaceae 6(1)

- Fagaceae 66(11)

$\rightarrow$ Juglandaceae $6(1)$

- Lauraceae 102(17)

$\rightarrow$ Magnoliaceae 6(1)

- Moraceae 24(4)

- Pentaphylacaceae $18(3)$

- Rutaceae 24(4)

$\rightarrow$ Sapindaceae $6(1)$

- Sapotaceae 6(2)

$\rightarrow$ Styracaceae $4(1)$

- Theaceae $18(3)$

species|family. The colored bars are predicted values by family, and the black bars are predicted values with respect to forest type. Count data for the number of individuals and species (in parenthesis) per family along the transect are shown in the legend. Letters denote the statistical groupings by forest type of a post-hoc Tukey HSD test

variation in traits was always significant with very large effect sizes, which spanned from 0.213 for root branching intensity to 0.531 for leaf area. Interactive effects between species and forest type were small to medium, and statistically significant in all cases, even when the effect forest type alone was nonsignificant, as was the case for leaf thickness and RTD.

We related root traits to the soil environment for 300 individuals of 50 species ( 3 per forest type of each species; Table 6 in the Appendix). The ANCOVA models showed that soil nutrient concentrations (i.e., soil BS and total N, P or K) interacted with forest type to significantly affect root morphologies in 3 of 16 cases. Interactive effects of soil $\mathrm{N}$ and $\mathrm{K}$ with forest type on root morphology were insignificant in all the cases (i.e., for all four traits); therefore, we limit the results to soil BS and total P. After controlling for species differences, soil BS had a significant interactive effect on SRL $\left(F_{247}^{1}=\right.$ $5.26, p<.05)$. Soil total $\mathrm{P}$ interacted with forest type to significantly affect $\operatorname{SRL}\left(F_{247}^{1}=4.45, p<.05\right)$ and $\operatorname{RTD}\left(F_{247}^{1}=\right.$ $5.26, p<.05)$ (Table 3 ). We fit individual regressions for the four root functional traits in relation to soil BS and total P. No relationships were found with respect to RTD or RBI (Fig. 5c and d; Table 3). Regressions were statistically significant for soil BS on root diameter in both primary and secondary forests (Fig. 5a; Table 3), and for SRL in primary forest (Fig. 5b; Table 3). Soil total $\mathrm{P}$ was negatively related to root diameter and positively related to SRL in primary forest only (Fig. 5; Table 3).

\section{Discussion}

We confirm widely reported plasticity in plant leaf area with light environment (Fig. 3), specifically the shaded 
Table 2 Analysis of variance table for linear models in the form: trait $\sim$ species|family $\times$ forest type. Prior to model fitting, traits were $\log _{10}$ transformed in the case of leaf area, root diameter, SRL, root tissue density, and root branching intensity to improve data normality

\begin{tabular}{|c|c|c|c|c|c|}
\hline Trait (units) & Source & $d f$ & $F$ & $p$ & $\omega^{2}$ \\
\hline \multirow[t]{4}{*}{ Leaf area $\left(\mathrm{cm}^{2}\right)$} & Species & 71 & 24.19 & $* * *$ & 0.531 \\
\hline & Forest type & 1 & 10.51 & $* *$ & 0.003 \\
\hline & Species $\times$ forest type & 58 & 3.21 & $* * *$ & 0.041 \\
\hline & Residuals & 1184 & - & - & - \\
\hline \multirow{4}{*}{ Specific leaf area $\left(\mathrm{m}^{2} \mathrm{~kg}^{-1}\right)$} & Species & 71 & 19.38 & $* * *$ & 0.451 \\
\hline & Forest type & 1 & 47.36 & $* * *$ & 0.016 \\
\hline & Species $\times$ forest type & 58 & 4.96 & $* * *$ & 0.079 \\
\hline & Residuals & 1183 & - & - & - \\
\hline \multirow[t]{4}{*}{ Leaf thickness (mm) } & Species & 69 & 22.54 & $* * *$ & 0.500 \\
\hline & Forest type & 1 & 1.69 & n.s. & 0.000 \\
\hline & Species $\times$ forest type & 57 & 5.73 & $* * *$ & 0.091 \\
\hline & Residuals & 1090 & - & - & - \\
\hline \multirow[t]{4}{*}{ Root diameter (mm) } & Species & 71 & 21.15 & $* * *$ & 0.404 \\
\hline & Forest type & 1 & 15.58 & $* * *$ & 0.004 \\
\hline & Species $\times$ forest type & 58 & 3.56 & $* * *$ & 0.042 \\
\hline & Residuals & 1818 & - & - & - \\
\hline \multirow[t]{4}{*}{ Specific root length $\left(\mathrm{m} \mathrm{kg}^{-1}\right)$} & Species & 71 & 10.26 & $* * *$ & 0.238 \\
\hline & Forest type & 1 & 7.10 & $* *$ & 0.002 \\
\hline & Species $\times$ forest type & 58 & 3.58 & $* * *$ & 0.054 \\
\hline & Residuals & 1818 & - & - & - \\
\hline \multirow[t]{4}{*}{ Root tissue density $\left(\mathrm{g} \mathrm{cm}^{-3}\right)$} & Species & 71 & 19.96 & $* * *$ & 0.397 \\
\hline & Forest type & 1 & 0.97 & n.s. & 0.000 \\
\hline & Species $\times$ Forest type & 58 & 2.69 & $* * *$ & 0.029 \\
\hline & Residuals & 1818 & - & - & - \\
\hline \multirow{4}{*}{ Root branching intensity (tips $\mathrm{cm}^{-1}$ ) } & Species & 71 & 9.76 & $* * *$ & 0.213 \\
\hline & Forest type & 1 & 81.66 & $* * *$ & 0.028 \\
\hline & Species $\times$ forest type & 58 & 5.72 & $* * *$ & 0.094 \\
\hline & Residuals & 1818 & - & - & - \\
\hline
\end{tabular}

Effect size $=\omega^{2}$, effect size $\left(\omega^{2}\right)$ values near 0.01 are considered small, near 0.06 are considered medium, and near 0.14 are considered large

$d f$ degrees of freedom, $M S$ mean squares, $n$.s. non-significant

${ }^{*} p<.05$

${ }^{* * *} p<.01$

**** $p<.001$

environmental conditions of saplings in older growth forest (Givnish 1984; Rijkers et al. 2000; Keenan and Niinemets 2017; Liu et al. 2016). In our study, shade-inhabiting saplings
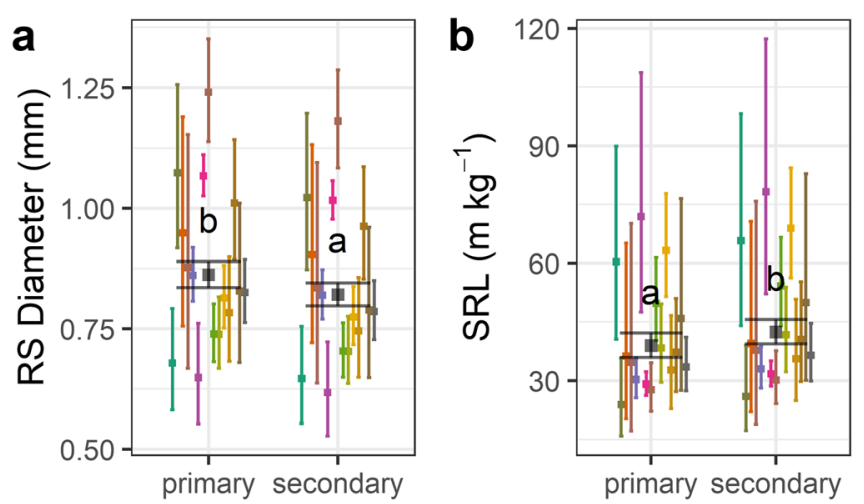

Fig. 4 Least-squares means (points) and 95\% confidence intervals (vertical bars) for four morphological root traits. Average root-system diameter (a), specific root length (SRL) (b), root tissue density (RTD) (c), and root branching intensity (RBI) (d) by forest type and plant family using data from 423 individuals from 72 species sampled along a $6.6-\mathrm{km}$ in primary forest had larger leaves than those in secondary forest (on average $6.5 \mathrm{~cm}^{2}$ greater in area, Fig. 3a). Variation in leaf morphologies was consistent across families, with a
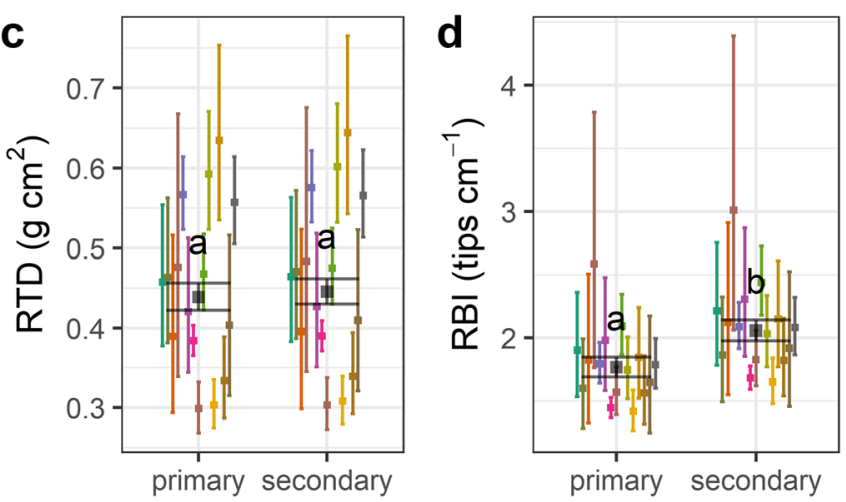

gradient from secondary to primary forest. The colored bars are predicted values by family (refer to legend of Fig. 3), and the black bars are predicted values with respect to forest type. Letters denote the statistical groupings by forest type of a post-hoc Tukey HSD tests 
Table 3 Regression results from least-squares linear models in the form of trait $\sim$ variable. Table to accompany Fig. 5. Models were fit separately by forest type

\begin{tabular}{|c|c|c|c|c|c|c|c|c|}
\hline Trait (units) & Forest type & Variable (units) & $\beta$ & se & $p$ & $F(1,148)$ & $R^{2}$ & RMSE \\
\hline \multirow[t]{4}{*}{ Root diameter (mm) } & Secondary & \multirow[t]{2}{*}{ Soil BS (\%) } & -0.004 & 0.002 & $*$ & 4.39 & 0.03 & 0.29 \\
\hline & Primary & & -0.010 & 0.004 & $*$ & 4.96 & 0.03 & 0.65 \\
\hline & Secondary & \multirow[t]{2}{*}{ Soil P $\left(\mathrm{g} \mathrm{kg}^{-1}\right)$} & -0.703 & 0.792 & n.s. & 0.79 & $<0.01$ & 0.29 \\
\hline & Primary & & -2.350 & 1.002 & $*$ & 5.50 & 0.04 & 0.26 \\
\hline \multirow[t]{4}{*}{ Specific root length $\left(\mathrm{m} \mathrm{kg}^{-1}\right)$} & Secondary & \multirow[t]{2}{*}{ Soil BS (\%) } & 0.262 & 0.188 & n.s. & 1.94 & 0.01 & 31.14 \\
\hline & Primary & & 1.171 & 0.551 & $*$ & 4.53 & 0.03 & 33.79 \\
\hline & Secondary & \multirow[t]{2}{*}{ Soil P $\left(\mathrm{g} \mathrm{kg}^{-1}\right)$} & 23.42 & 84.80 & n.s. & 0.08 & $<0.01$ & 31.33 \\
\hline & Primary & & 324.04 & 128.32 & $*$ & 6.38 & 0.04 & 33.58 \\
\hline \multirow[t]{4}{*}{ Root tissue density $\left(\mathrm{g} \mathrm{cm}^{-3}\right)$} & Secondary & \multirow[t]{2}{*}{ Soil BS (\%) } & 0.001 & 0.001 & $n . s$ & 0.07 & $<0.01$ & 0.20 \\
\hline & Primary & & -0.002 & 0.003 & $n . s$ & 0.73 & $<0.01$ & 0.16 \\
\hline & Secondary & \multirow[t]{2}{*}{ Soil P $\left(\mathrm{g} \mathrm{kg}^{-1}\right)$} & 0.837 & 0.540 & n.s. & 2.40 & 0.02 & 0.20 \\
\hline & Primary & & -0.523 & 0.613 & n.s. & 0.73 & $<0.01$ & 0.16 \\
\hline \multirow[t]{4}{*}{ Root branching intensity (tips $\mathrm{cm}^{-1}$ ) } & Secondary & Soil BS (\%) & -0.001 & 0.004 & $n . s$ & 0.02 & $<0.01$ & 0.72 \\
\hline & Primary & \multirow{3}{*}{ Soil P $\left(\mathrm{g} \mathrm{kg}^{-1}\right)$} & 0.002 & 0.011 & $n . s$ & 0.02 & $<0.01$ & 0.65 \\
\hline & Secondary & & 3.188 & 1.922 & $n . s$ & 2.75 & 0.02 & 0.65 \\
\hline & Primary & & -0.48 & 1.922 & $n . s$ & 2.75 & 0.02 & 0.72 \\
\hline
\end{tabular}

Model coefficient estimates $(\beta)$, standard errors (se), and associated probabilities $(p)$ are given for each variable by forest type (intercept terms are not shown). Regression $F$-statistics $(F)$ and coefficients of determination $\left(R^{2}\right)$ and root-mean-squared error $(R M S E)$ are given for each model. The $F(1,148)$ critical value at $\alpha=0.05$ is 3.905. Italicized model coefficients show significant ANCOVA interaction terms between forest type and soil variable $(p<0.05)$

n.s. non-significant

Probabilities are denoted as follows:

$* p<.05$

$* * p<.01$

$* * * p<.001$

wide range in leaf morphological traits (Fig. 3). On average, SLA was $1.2 \mathrm{~m}^{2} \mathrm{~kg}^{-1}$ greater in secondary than primary forest, so area-based variation in leaf morphology accounted for most of the variation is SLA with forest type (Fig. 3). Our results are, however, inconsistent with those of Rijkers et al. (2000), who found that SLA of four tropical forest tree species in French Guiana halved from to 25 to $12.5 \mathrm{~m}^{2} \mathrm{~kg}^{-1}$ as canopy openness increased from 0 to $25 \%$. In 2008 , leaf area index in the secondary forest portion of the transect measured about 5 , whereas leaf area index in the primary forest portion of the transect measured approximately 6.5 (Qui 2008), so the canopy openness gradient between primary and secondary forest in our study was not as steep as that of Rijkers et al., with negligible observable differences in openness.

Generally, root traits varied more than leaf traits across forest types, with root diameter and root tissue density varying less than that of SRL and root topology (i.e., RBI). These results suggest that there exist two or more axes of root morphological variation (Weemstra et al. 2016; Kramer-Walter et al. 2016). The first axis encompasses root diameter and root tissue density, which we found to be less-plastic across soil conditions and more-constrained by plant lineage (i.e., the evolved root strategy of the species), whether that be one of thicker or thinner roots (Valverde-Barrantes et al. 2017; Maherali 2017). The second, associated with SRL and root topology, was more variable with soil-fertility and texture. This second axis seeks to optimize root structural investment into a topology that is most efficient for nutrient foraging, with some potential trade-offs between purely abiotic and abiotically assisted ways in doing so (e.g., associations with mycorrhizae and chemical alterations of the rhizosphere; Fitter 1991; Lynch et al. 2005; Craine 2006; McCormack and Iversen 2019).

SRL, or the distance a root can travel for a given amount of structural investment, trades off with the production of absorptive fine-root tips (i.e., branching intensity), and thus, species seek to optimize nutrient foraging with root architecture in a wide variety of morphologies. For example, the Fagaceae species in this study have a highly dichotomously branched root system with a network of fine root tips that form an absorptive mat just under the leaf litter layer, while the 

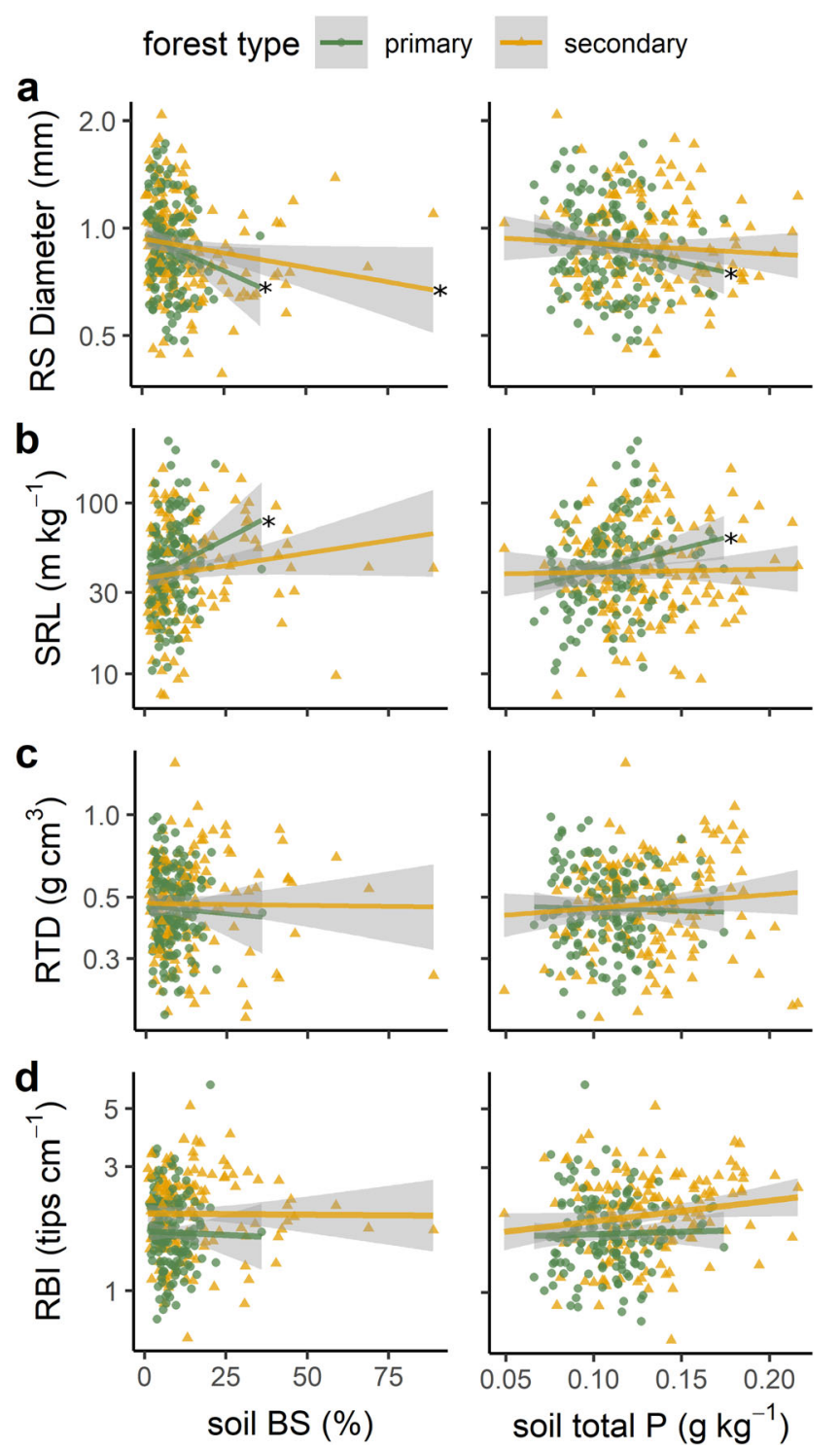

Fig. 5 Relationships between root functional traits (average root system diameter, RS Diameter, specific root length, SRL, root tissue density, RTD, and root branching intensity, RBI) ) and soil variables (base saturation, soil BS, and total phosphorus, soil total P). Points show average individual trait values for 3-5 root systems ( $y$-axis) and soil percent base saturation and phosphorus content of $1 \mathrm{~kg}$ of soil collected from where root systems were excavated ( $x$-axis) for 300 individuals of 50 species (see Table 6 in the Appendix). Lines represent ordinary least-squares regression, with $95 \%$ confidence intervals (shading) in the form of trait $\sim$ soil variable. Models were fit separately by forest type (see Table 3 ). Asterisks show statistically significant regression slopes $(\alpha=0.05)$

Lauraceae have a much more herringbone architecture with a long slender transportive root that supports many short lateral roots, which occupy the mineral soil layer several inches below the soil surface. Root system stratification within the soil profile is common in temperate forest systems where few species compete for soil resources (Parish and Bazzaz 1976). In the tropical forests of southern China, where temperate and tropical taxa have mixed to a large degree (Zhu 2017), such separation via complimentary resource acquisition strategies within the soil profile may promote species coexistence (Guo et al. 2008; Ma et al. 2018; Lu and Hedin 2019).

Within species, tropical forest saplings can modulate the root length-branching intensity trade-off in root architecture with local-scale variation in the soil environment. In soil where nutrients are more abundant, root systems prioritize acquisitive architectures (e.g., higher SRL and RBI; Fig. 4), yet where competition for soil nutrients is high (i.e., in primary forest), root systems employ slightly more-conservative morphologies, such as slight increases in root diameter, and likely seek to maximize root lifespan to hold on to soil space (Craine 2006). Other studies have found highly variable root system morphologies with the soil environment. Generally, Ndepleted soils lead to increased lateral root elongation, while P-depleted soils cause more branched root systems (LópezBucio et al. 2003; Giehl et al. 2013). Notably, along verystrong P gradients, plant species have been shown to modulate root morphologies and nutrient acquisition strategies in relation to how they partition soil $\mathrm{P}$, with more enzymatic activity and more-architecturally advanced roots in P-improvised soils (Lambers et al. 2006; Niu et al. 2013; Zemunik et al. 2015; Lambers et al. 2017). In a meta-analysis of the factors affecting tropical tree root morphologies, Addo-Danso et al. (2019) reported that SRL was positively related (albeit weakly) to soil $\mathrm{P}$ and base saturation.

P-poor, highly weathered, leached tropical soils, such as the yellow soils of JFL, are also thought to have the ability to support a high diversity of plant species because of the way they allow plants to diversify and partition nutrient-use strategies in many ways within the soil environment (Laliberté et al. 2015; Turner 2008; Turner et al. 2018). Moreover, in Syzygium castaneum roots in a tropical forest in Borneo, root diameter decreased, and specific root length, root surface area, and root phosphatase enzymatic activity all increased with decreasing soil available P (Ushio et al. 2015). Soil N, P, and base saturation all decrease along the gradient from secondary to primary forest in JFL (Table 1). Increasing soil base saturation led to a slight decrease in root system diameter in both primary and secondary forests, with the decreases in primary forest being slightly greater than those in secondary forest, despite the soils occupying a smaller range of soil base saturation values (Fig. 5a; Table 3). Increasing soil total $\mathrm{P}$ had a negative relationship on root diameter, but only in primary forest (Fig. 5a; Table 3). Similarly, soil base saturation and total $\mathrm{P}$ were positively related to SRL, but only in primary forest (Fig. 5b; Table 3). Regressions included very high variance, similar to those reported in other studies (i.e., with low coefficients of determination, see Addo-Danso et al. 2019), 
because at the local scale of the analysis, we have a relatively low range in soil nutrients when compared with the range of variation throughout the tropics (Addo-Danso et al. 2019), and because we controlled for taxonomic identity across the gradient, potentially limiting any environmental-filtering effects (Table 6 in the Appendix). These results support that the root morphologies of the tropical saplings studied here employ many root functional trait strategies to inhabit similar soil environments in both primary and secondary forest (Mommer and Weemstra 2012; Bardgett et al. 2014; Weemstra et al. 2016; Laliberté 2017).

We are unable to assess if investment in root tissues (i.e., allocation to root biomass) is greater in primary than secondary forest, although some research has shown that root biomass increases with forest age (Jackson et al. 1996; Leuschner et al. 2009). Using root coring sampling methods, Hertel et al. (2003) found that fine root biomass increased with increasing forest age, but also found more root tips per unit area in the mineral soil of early and mid-successional than in primary wet forest in Costa Rica, estimating 560,000 tips $\mathrm{m}^{-2}$ in the former and 260,000 tips $\mathrm{m}^{-2}$ in the latter. In tropical forests, as fine root biomass increases with succession (Hopkins et al. 1996; Powers and Peréz-Aviles 2013), intraspecific shifts toward a more-conservative strategy that maximizes root lifespan would seem advantageous, because competition for soil space is greater in latesuccessional forest relative to secondary forest (Jackson et al. 1996; Craine 2006). Because of differences in soil space availability, root morphologies in primary forest may favor the production of thicker roots with more root tips over the elongation of roots, whereas roots in secondary forest may favor the opposite.

These morphological differences are subtle, evidenced by relatively weak effect sizes of forest type in the ANOVA models (Table 2). Some previous work supports that claim; indeed, Zangaro et al. (2012) reported increased root diameters, but no difference in SRL or root length for mature relative to secondary Araucaria forests of the southern Brazilian Pantanal. Hopkins et al. (1996) reported that SRL in secondary forest was twice that of primary forests in Acacia-dominated wet forests of northern Australia. Several previous studies have also demonstrated that SRL increases with soil fertility (Ostonen et al. 2007; Kong et al. 2014). We found that differences in root diameter by forest type were highly conserved and consistent across the 15 Angiosperm families we measured (Fig. 4; Comas and Eissenstat 2009; Kong et al. 2014; Valverde-Barrantes et al. 2017). In the ANOVA models (Table 2), interaction effects between plant lineage and forest type were statistically significant, meaning that there was some difference in the magnitude of the response of each species to forest type, even though all plant lineages responded similarly in terms of direction (Figs. 3 and 4). Examining comparable root systems across individuals, we provide evidence for juvenile tropical trees, that intraspecific variation in root diameter in relation to the soil environment is ubiquitous and potentially consistent, albeit small in magnitude. Our results suggest that variation in root diameter trades off with investment of structural resources in root length (SRL) or root tips (RBI).

\section{Conclusion}

With increasing forest age, plasticity in leaf morphologies showed an acquisitive shift, but variation in root morphologies and architectures showed conservative shifts, which was contrary to our hypothesis where we predicted acquisitive morphological shifts for both leaves and roots with increasing forest age. Intraspecific variation in leaf and root morphologies was consistent across plant lineages, although large interspecific differences in leaf and root trait measurements were observed. Leaves were larger in primary forest than in secondary forest. Root-system diameter increased, and root systems were less architecturally developed (i.e., had fewer root tips per unit length) in primary than in secondary forest (Figs. 3 and 4). These results exemplify how the soil environment can control root morphology in an abiotic context (Powers and Peréz-Aviles 2013; Freschet et al. 2017; AddoDanso et al. 2019).

Intraspecific morphological shifts were observed along functional axes toward more-conservative root strategies; however, one major limitation of this study lies in its inability to investigate if such shifts are accompanied with any compensation via biotic methods of acquiring nutrients (i.e., more association with mycorrhizal symbionts, increases in root enzymatic activity, or shifts in chemical partitioning of soil nutrients; McCormack and Iversen 2019) among primary and secondary forest areas. Some research has shown root diameter to be correlated to mycorrhizal colonization, and it would make sense that thicker roots, in later-successional forest, are morebiotically reliant on mycorrhizae for in their nutrients (Phillips et al. 2013; Rosling et al. 2016; Kong et al. 2017; McCormack and Iversen 2019). In older forests where the leaf litter layer is thicker and of greater quality (i.e., higher $\mathrm{C}: \mathrm{N}$ ratio), ectomycorrhizal roots, such as those of many of the Fagaceae species in this study, forage nutrients directly from leaf detritus via fungal hyphae to a greater degree than in forests where leaf litter layers are thinner or of lower quality (Phillips et al. 2013). Although we demonstrate morphological plasticity of root morphologies with local, variation in the soil environment

\section{פ2 Springer INRAC}


(i.e., soil total $\mathrm{P}$ and base saturation; Fig. 5; Table 3), additional data are needed to confirm differences in root function (Warren et al. 2015).

By comparing fine root systems and leaves of the same individuals, we illustrate a decoupling of intraspecific variation in leaf and root morphologies. Although leaves became increasingly acquisitive from secondary to primary forestincreasing leaf area, and decreasing SLA, root systems showed conservative intraspecific shifts-increasing root diameter and decreasing SRL and RBI. This could be indic- ative of the relative strength of aboveground-belowground plant competition, in that from secondary to primary forest, sapling competition for light tends to increase, potentially changing the aboveground-belowground competition balance. We show this competitive balance operates consistently across the roots systems and leaves of 15 Angiosperm families, potentially helping predict how plant organ morphologies vary with local-scale variation in tropical forest environment and age.

\section{List of abbreviated terms (in order of appearance in the manuscript text)}

\begin{tabular}{|c|c|c|c|}
\hline Abbreviation & Complete term & Definition & Units \\
\hline SLA & Specific leaf area & $\begin{array}{l}\text { The ratio of the leaf area to leaf dry mass. The inverse of leaf mass per area. } \\
\text { Our measurements of SLA include the leaf petiole and were done using complete } \\
\text { leaves (i.e., included the petiole and all leaflets for compound leaves). }\end{array}$ & $\mathrm{m}^{2} \mathrm{~kg}^{-1}$ \\
\hline SRL & Specific root length & The ratio of total linear length of root system to the root system dry mass. & $\mathrm{m} \mathrm{kg}^{-1}$ \\
\hline SRA & Specific root surface area & The ratio of the entire root system area to its dry mass. & $\mathrm{m}^{2} \mathrm{~kg}^{-1}$ \\
\hline SRTA & Specific root tip abundance & The ratio of the number or terminal, first-order root tips to root system dry mass. & tips $g$ \\
\hline RBI & Root branching intensity & The ratio of the number or terminal, first-order root tips to the total root system length. & tips $\mathrm{cm}^{-1}$ \\
\hline RTD & Root tissue density & $\begin{array}{l}\text { The root system dry mass divided by the total root system volume. RTD calculation } \\
\text { assumes circularity of roots, WinRhizo estimates root system volume from diameter. }\end{array}$ & $\mathrm{g} \mathrm{cm}^{-3}$ \\
\hline BS & Soil base saturation & $\begin{array}{l}\text { The percentage of soil cation exchange capacity occupied by base cations-calculated } \\
\text { as the ratio of total exchangeable bases }(\times 100) \text { to the soil total exchangeable bases } \\
\text { (both of which were measured using in the lab using the ammonium acetate } \\
\text { exchange-flame atomic absorption method). }\end{array}$ & $\%$ \\
\hline
\end{tabular}

Acknowledgments We thank the anonymous reviewers for comments that improved this work. We thank Sheyla Santana from the FIU GIS lab for her help producing Fig. 1. We acknowledge the assistance of the following people who helped in the field and with the processing of plant samples: Shaojun Ling, Yaxin Xie, Jaming Wang, Siqi Yang, Wenguang Tang, Shitaing Ma, Qiqi Zhang, and Jiazhu Shi. Assistance with taxonomic field identification was provided by Professor $\mathrm{Yu}$ from the Jianfengling Forest Bureau.

Funding information JAH received support via a short-term fellowship from CTFS-ForestGEO at the Smithsonian. We thank Stuart J. Davies. Additionally, we are grateful for many small personal donations that helped fund the soil analyses (http://www.experiment.com/chinaroots).
Data availability The datasets generated and analyzed for this study are available on the FigShare repository: https://doi.org/10.6084/m9.figshare. 7996328

\section{Compliance with ethical standards}

Conflict of interest The authors declare that they have no conflict of interest. 


\section{Appendix}
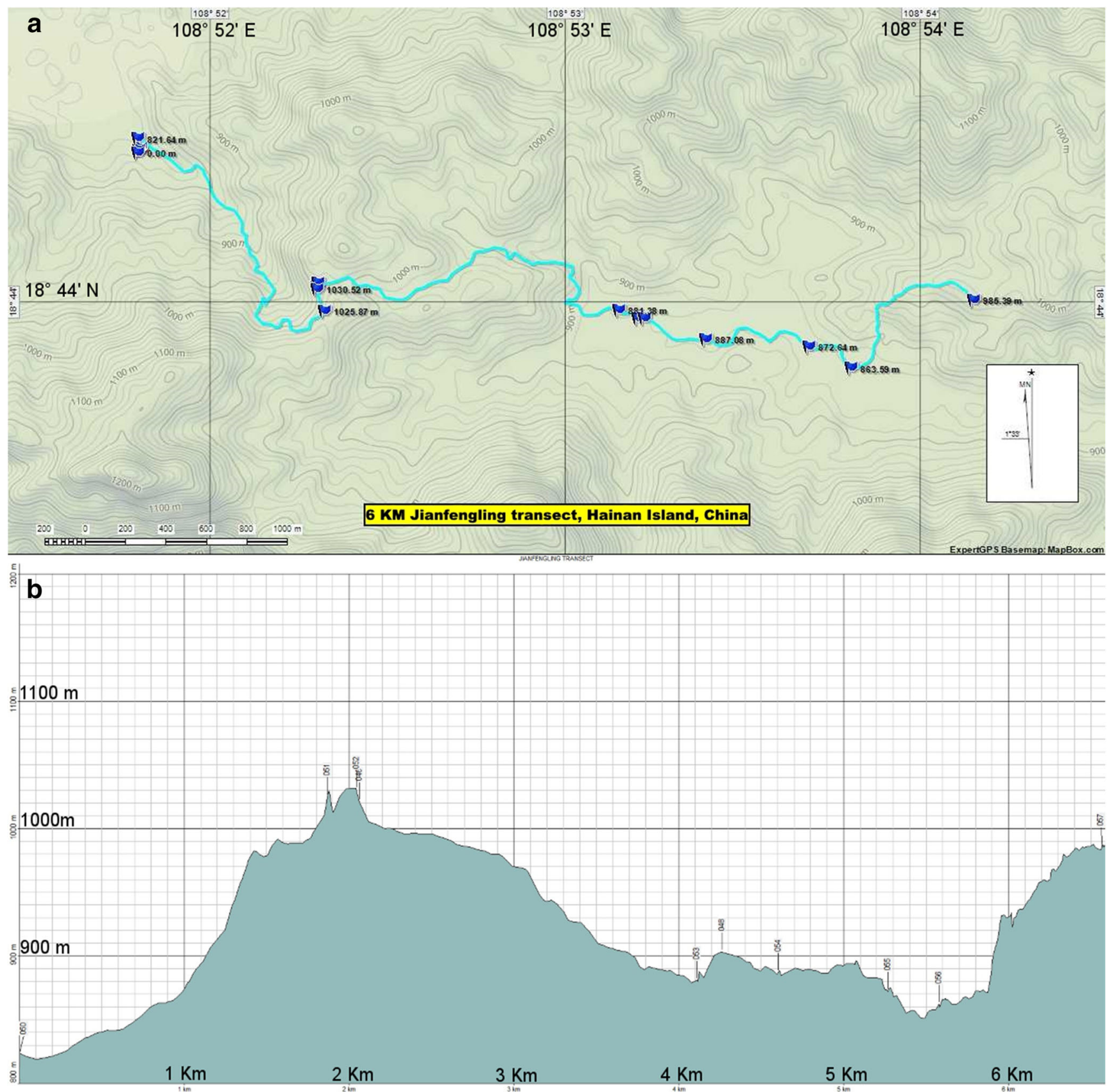

Fig. 6 Detailed topographic map (a) and topographic profile (b) of the 6.6- $\mathrm{km}$ transect in the Jianfengling Forest Reserve, Hainan Island, China, where functional traits of saplings were sampled. The transect started near the Jianfengling field house, at the entrance of the forest reserve. It

progressed over one mountain, and over a stream (at $\mathrm{km} 4$ of the transect), which delineated the secondary and primary areas of forest. At roughly $\mathrm{km} 5.5$ of the transect, the transect entered the 60-ha CTFSForestGEO permanent forest dynamic plot 
Fig. 7 Principle component analysis (variable scores plotted) of 7 leaf traits measured on 423 saplings of 72 species. Raw trait measurements were first scaled and centered

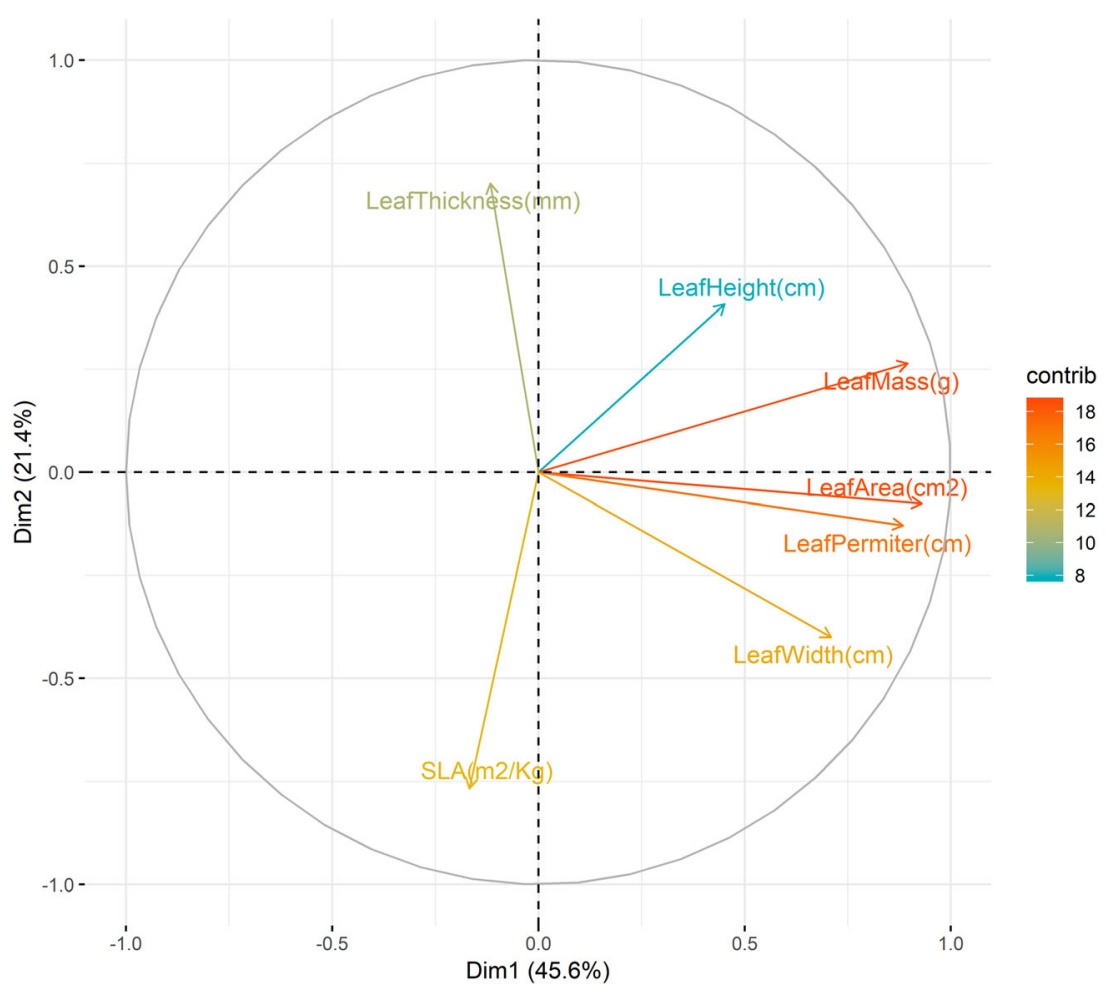

Table 4 PCA loadings for the first three principal components for 7 leaf traits. Traits used in analysis of variance models are bolded

\begin{tabular}{llll}
\hline Variable & PC1 & PC2 & PC3 \\
\hline Leaf area $\left(\mathbf{c m}^{\mathbf{2}}\right)$ & $\mathbf{0 . 5 2 0}$ & $-\mathbf{0 . 0 6 2}$ & $\mathbf{0 . 0 5 8}$ \\
Leaf permiter $(\mathrm{cm})$ & 0.494 & -0.105 & 0.057 \\
Leaf width $(\mathrm{cm})$ & 0.379 & -0.327 & -0.491 \\
Leaf height $(\mathrm{cm})$ & 0.253 & 0.333 & 0.738 \\
Leaf mass $(\mathrm{g})$ & 0.501 & 0.216 & -0.076 \\
SLA $\left(\mathbf{m}^{\mathbf{2}} \mathbf{~ k g}^{-\mathbf{1}}\right)$ & $\mathbf{- 0 . 0 9 4}$ & $\mathbf{0 . 3 3 6}$ & $\mathbf{0 . 3 3 6}$ \\
Leaf thickness $(\mathbf{m m})$ & $-\mathbf{0 . 0 6 5}$ & $\mathbf{0 . 5 7 3}$ & $-\mathbf{0 . 2 9 7}$ \\
\hline
\end{tabular}


Fig. 8 Principle components analysis (variable scores plotted) of 7 key root traits measured on 423 saplings of 72 species. Raw trait measurements were first scaled and centered

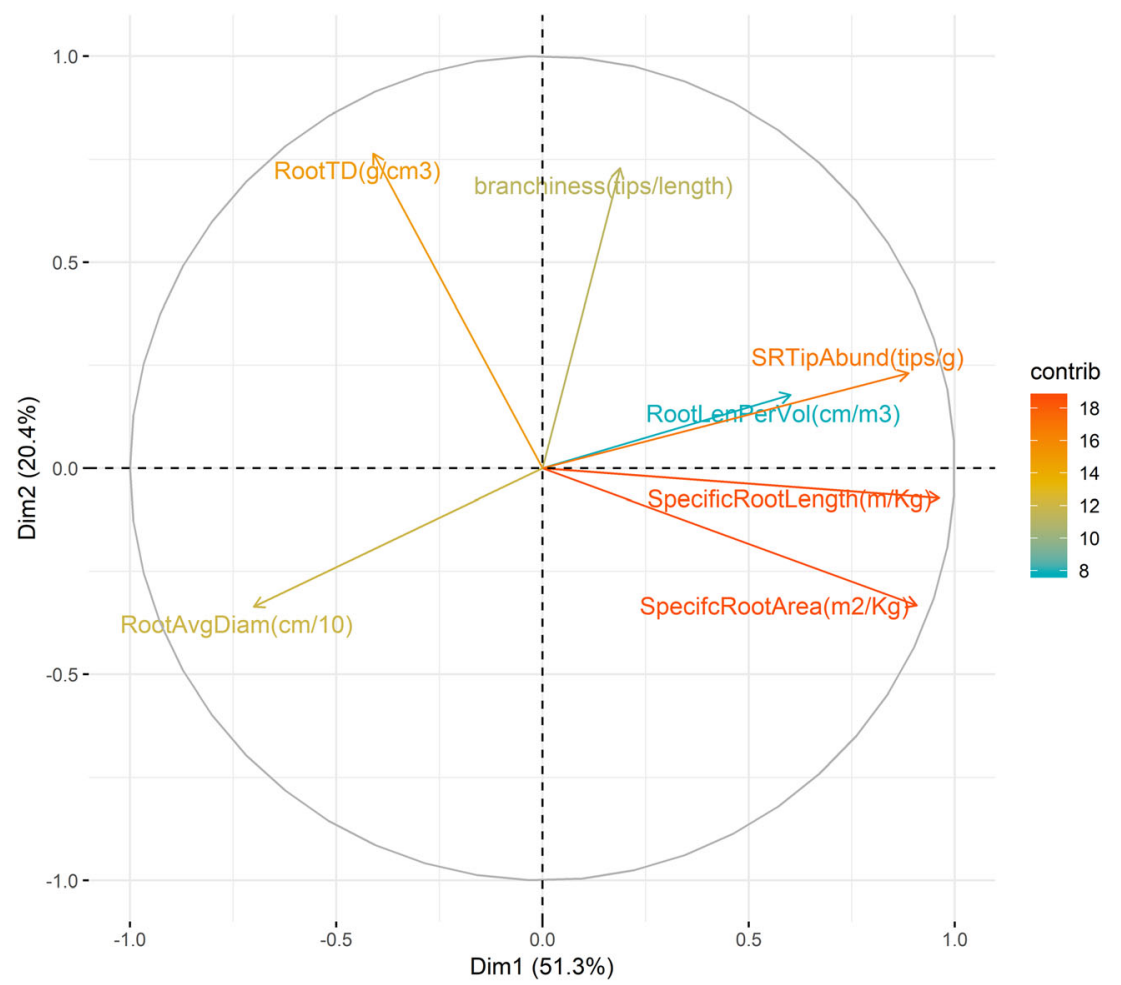

Table 5 PCA loadings for the first three principal components for 7 root traits. Traits used in analysis of variance models are bolded

\begin{tabular}{|c|c|c|c|}
\hline Variable & $\mathrm{PC} 1$ & $\mathrm{PC} 2$ & PC3 \\
\hline Root length $(\mathrm{cm})$ & 0.317 & 0.149 & 0.532 \\
\hline Specific root length $\left(\mathrm{m} \mathrm{kg}^{-1}\right)$ & 0.508 & -0.060 & -0.012 \\
\hline Specific root area $\left(\mathrm{m}^{2} \mathrm{~kg}^{-1}\right)$ & 0.479 & -0.278 & -0.086 \\
\hline Root avg diam $\left(\mathrm{cm} \mathrm{10}^{-1}\right)$ & -0.369 & -0.281 & -0.372 \\
\hline $\operatorname{Root} T D\left(\mathrm{~g} \mathrm{~cm}^{-3}\right)$ & -0.216 & 0.639 & 0.345 \\
\hline Branchiness (tips $\mathbf{c m}^{-1}$ ) & 0.099 & 0.610 & -0.620 \\
\hline SRTipAbund (tips $\mathrm{g}^{-1}$ ) & 0.468 & 0.193 & -0.263 \\
\hline
\end{tabular}


Table 6 Individual collection counts of species along the 6-km JFL transect (Figs. 1 and 6) by forest type. For each individual sapling three to five fine root systems and three leaves were collected. Bolded species denote those where soil samples were analyzed each primary and secondary forest, totaling 300 individuals of 50 species. Data from those 300 individuals are used in Fig. 5 and Table 3)

\begin{tabular}{|c|c|c|c|}
\hline \multirow[t]{2}{*}{ Species } & \multirow[t]{2}{*}{ Family } & \multicolumn{2}{|c|}{ No. of individuals } \\
\hline & & Secondary & Primary \\
\hline Acronychia pedunculata (L.) Miq. & Rutaceae & 3 & 4 \\
\hline Adinandra hainanensis Hayata & Pentaphylacaceae & 4 & 6 \\
\hline Alniphyllum fortunei (Hemsl.) Makino & Styracaceae & 1 & 3 \\
\hline Alseodaphne hainanensis Merr. & Lauraceae & 3 & 3 \\
\hline Artocarpus styracifolius Pierre & Moraceae & 3 & 3 \\
\hline Beilschmiedia laevis C.K.Allen & Lauraceae & 3 & 3 \\
\hline Canarium album (Lour.) DC. & Burseraceae & 5 & 3 \\
\hline Canarium pimela K.D.Koenig & Burseraceae & 0 & 2 \\
\hline Castanopsis faberi Hance & Fagaceae & 0 & 2 \\
\hline Castanopsis fissa (Champ. ex Benth.) Rehder \& E.H.Wilson & Fagaceae & 3 & 3 \\
\hline Castanopsis tonkinensis Seemen & Fagaceae & 4 & 3 \\
\hline Cinnamomum burmanni (Nees \& T.Nees) Blume & Lauraceae & 3 & 3 \\
\hline Cinnamomum porrectum (Roxb.) Meisn. & Lauraceae & 4 & 4 \\
\hline Cinnamomum rigidissimum H.T.Chang & Lauraceae & 4 & 3 \\
\hline Cleyera obscurinervia (Merr. \& Chung) H.T.Chang & Pentaphylacaceae & 3 & 6 \\
\hline Cryptocarya chinensis Hance (Hemsl.) & Lauraceae & 5 & 3 \\
\hline Cryptocarya chingii W.C. Cheng & Lauraceae & 3 & 4 \\
\hline Dasymaschalon rostratum Merr \& Chun. & Annonaceae & 4 & 3 \\
\hline Diospyros morrisiana Hance & Ebenaceae & $\mathbf{0}$ & 2 \\
\hline Eurya ciliata Merr. & Pentaphylacaceae & 3 & 5 \\
\hline Engelhardia roxbughiana Wall. & Juglandaceae & 3 & 3 \\
\hline Engelhardia spicata var. colebrookeana (Lindl. ex Wall.) Koord. \& Valeton & Juglandaceae & 0 & 1 \\
\hline Engelhardia unijuga (Lindl. ex Wall.) Iljinsk. & Juglandaceae & 0 & 3 \\
\hline Ficus formosana Maxim. & Moraceae & 3 & 3 \\
\hline Ficus hirta Vahl & Moraceae & 3 & 3 \\
\hline Ficus vasculosa Wall. ex Miq. & Moraceae & 3 & 4 \\
\hline Lindera kwangtungensis (H. Liu) C.K. Allen & Lauraceae & 3 & 3 \\
\hline Lindera nacusua (D. Don) Merr. & Lauraceae & 0 & 3 \\
\hline Lindera robusta (C.K. Allen) H.B. Cui & Lauraceae & 4 & 3 \\
\hline Magnolia championii Benth. & Magnoliaceae & 3 & 3 \\
\hline Lithocarpus amygdalifolius (Skan) Hayata & Fagaceae & 6 & 3 \\
\hline Lithocarpus fenestratus (Roxb.) Rehder & Fagaceae & 3 & 2 \\
\hline Lithocarpus fenzelianus A.Camus & Fagaceae & 3 & 3 \\
\hline Lithocarpus hancei (Benth.) Rehder & Fagaceae & 0 & 1 \\
\hline Lithocarpus handelianus A.Camus & Fagaceae & 0 & 1 \\
\hline Lithocarpus howii Chun & Fagaceae & 0 & 2 \\
\hline Lithocarpus longipedicellatus (Hickel \& A.Camus) A.Camus & Fagaceae & 3 & 3 \\
\hline Lithocarpus pseudovestitus A.Camus & Fagaceae & 4 & 4 \\
\hline Litsea baviensis Lecomte & Lauraceae & 4 & 3 \\
\hline Litsea variabilis Hemsl. & Lauraceae & 3 & 3 \\
\hline Litsea verticillata Hance & Lauraceae & 4 & 3 \\
\hline Machilus chinensis (Benth.) Hemsl. & Lauraceae & 2 & 5 \\
\hline Machilus cicatricosa S.K. Lee & Lauraceae & 5 & 4 \\
\hline Machilus monticola S.K. Lee & Lauraceae & 3 & 3 \\
\hline Maclurodendron oligophlebium (Merr.) T.G. Hartley & Rutaceae & 4 & 3 \\
\hline
\end{tabular}


Table 6 (continued)

Species

Family

No. of individuals

\begin{tabular}{|c|c|c|c|}
\hline & & \\
\hline & & Secondary & Primary \\
\hline Madhuca hainanensis Chun \& F.C.How & Sapotaceae & 4 & 3 \\
\hline Manglietia fordiana var. hainanensis (Dandy) Noot. & Magnoliaceae & 3 & 3 \\
\hline Melicope chunii T.G. Hartley & Rutaceae & 3 & 3 \\
\hline Magnolia balansae A.DC. & Magnoliaceae & 3 & 3 \\
\hline Michelia mediocris (Dandy) Figlar & Magnoliaceae & 5 & 3 \\
\hline Neolitsea cambodianai Lecomte & Lauraceae & 5 & 4 \\
\hline Neolitsea ellipsoidea C.K. Allen & Lauraceae & 3 & 3 \\
\hline Neolitsea oblongifolia Merr. \& Chun. & Lauraceae & 3 & 3 \\
\hline Neolitsea ovatifolia Yen. C. Yang \& P.H. Huang & Lauraceae & 3 & 4 \\
\hline Neolitsea pulchella (Meisn.) Merr. & Lauraceae & 3 & 3 \\
\hline Nephelium topengii (Merr.) H.S. Lo & Sapindaceae & 4 & 4 \\
\hline Phoebe hungmoensis S.K. Lee & Lauraceae & 0 & 4 \\
\hline Polyspora hainanensis (Hung T. Chang) C.X. Ye ex B.M. Barthol. \& T.L. Ming & Theaceae & 3 & 3 \\
\hline Planchonella annamensis Pierre ex Dubard & Sapotaceae & 0 & 2 \\
\hline Pyrenaria jonquieriana subsp. multisepala (Merr. \& Chun) S.X. Yang & Theaceae & 3 & 3 \\
\hline Litsea baviensis Lecomte & Lauraceae & 3 & 3 \\
\hline Litsea variabilis Hemsl. & Lauraceae & 3 & 3 \\
\hline Litsea verticillata Hance & Lauraceae & 3 & 3 \\
\hline Quercus auricoma A.Camus & Fagaceae & 2 & 3 \\
\hline Quercus myrsinifolia Blume. & Fagaceae & 3 & 3 \\
\hline Quercus asymmetrica Hickel \& A.Camus & Fagaceae & 3 & 3 \\
\hline Sarcosperma laurinum (Benth.) Hook.f. & Sapotaceae & 3 & 3 \\
\hline Schima superba Gardner \& Champ. & Theaceae & 4 & 5 \\
\hline Streblus indicus (Bureau) Corner & Moraceae & 0 & 3 \\
\hline Tetradium glabrifolium (Champ. ex Benth) T.G. Hartley & Rutaceae & 0 & 3 \\
\hline Toxicodendron vernicifluum (Stokes) F.A. Barkley & Anacardiaceae & 4 & 3 \\
\hline Zanthoxylum avicennae (Lam.) DC. & Rutaceae & 3 & 3 \\
\hline
\end{tabular}

\section{References}

Ackerly D, Knight C, Weiss S, Barton K, Starmer K (2002) Leaf size specific leaf area and microhabitat distribution of chaparral woody plants: contrasting patterns in species level and community level analyses. Oecologia 130:449-457

Addo-Danso SD, Defrenne CE, McCormack ML, Ostonen IV, AddoDanso A, Foli EG, Borden KA, Isaac ME, Prescott CE (2019) Fine-root morphological trait variation in tropical forest ecosystems: an evidence synthesis. Plant Ecol 221:1-13

Baraloto C, Paine CET, Poorter L, Beauchene J, Bonal D, Domenach AM, Hérault B, Patiño S, Roggy J-C, Chave J (2010) Decoupled leaf and stem economics in rain forest trees. Ecol Lett 13:1338-1347

Bardgett RD, Mommer L, De Vries FT (2014) Going underground: root traits as drivers of ecosystem processes. Trends Ecol Evol 29:692-699

Bloom AJ, Chapin FS, Mooney HA (1985) Resource limitation in plantsan economic analogy. Annu Rev Ecol Evol Syst 16:363-392

Chave J, Coomes D, Jansen S, Lewis SL, Swenson NG, Zanne AE (2009) Towards a worldwide wood economics spectrum. Ecol Lett 12:351-366
Chen W, Koide RT, Adams TS, DeForest JL, Cheng L, Eissenstat DM (2016) Root morphology and mycorrhizal symbioses together shape nutrient foraging strategies of temperate trees. P Natl Acad Sci USA 113:8741-8746

Christensen NL, Peet RK (1984) Convergence during secondary forest succession. J Ecol 72:25-36

Comas L, Eissenstat D (2009) Patterns in root trait variation among 25 coexisting North American forest species. New Phytol 182:919-928

Craine JM (2006) Competition for nutrients and optimal root allocation. Plant Soil 285:171-185

Craine JM, Froehle J, Tilman D, Wedin D, Chapin FS (2001) The relationships among root and leaf traits of 76 grassland species and relative abundance along fertility and disturbance gradients. Oikos 93:274-285

Defrenne CE, McCormack ML, Roach WJ, Addo-Danso SD, Simard SW (2019) Intraspecific Fine-root trait-environment relationships across interior Douglas-fir forests of Western Canada. Plants 8:199

Díaz S, Kattge J, Cornelissen JH, Wright IJ, Lavorel S, Dray S, Reu B, Kleyer M, Wirth C, Prentice IC (2016) The global spectrum of plant form and function. Nature 529:167-171 
Eissenstat D, Wells C, Yanai R, Whitbeck J (2000) Building roots in a changing environment: implications for root longevity. New Phytol 147:33-42

Eissenstat DM, Kucharski JM, Zadworny M, Adams TS, Koide RT (2015) Linking root traits to nutrient foraging in arbuscular mycorrhizal trees in a temperate forest. New Phytol 208:114-124

Flores O, Garnier E, Wright IJ, Reich PB, Pierce S, Diaz S, Pakeman RJ, Rusch GM, Bernard-Verdier M, Testi B, Bakker JP (2014) An evolutionary perspective on leaf economics: phylogenetics of leaf mass per area in vascular plants. Ecol Evol 4:2799-2811

Fitter A (1991) Characteristics and functions of root systems. In: Waisel Y, Eschel A, Beeckman T, Kafkafi U (eds) Plant roots: the hidden half, 3rd edn. Marcel Decker Inc., New York, pp 49-78

Fitter A, Stickland T (1991) Architectural analysis of plant root systems 2. Influence of nutrient supply on architecture in contrasting plant species. New Phytol 118:383-389

Fortunel C, Fine PVA, Baraloto C (2012) Leaf, stem and root tissue strategies across 758 Neotropical tree species. Funct Ecol 26: 1153-1161

Freschet GT, Roumet C (2017) Sampling roots to capture plant and soil functions. Funct Ecol 31:1506-1518

Freschet GT, Valverde-Barrantes OJ, Tucker CM, Craine JM, McCormack ML, Violle C, Fort F, Blackwood CB, Urban-Mead KR, Iversen CM (2017) Climate soil and plant functional types as drivers of global fine-root trait variation. J Ecol 105:1182-1196

Garnier E, Shipley B, Roumet C, Laurent G (2001) A standardized protocol for the determination of specific leaf area and leaf dry matter content. Funct Ecol 15:688-695

Giehl RF, Gruber BD, von Wirén N (2013) It's time to make changes: modulation of root system architecture by nutrient signals. J Exp Bot 65:769-778

Givnish T (1984) Leaf and canopy adaptations in tropical forests. In: Medina E, Mooney HA, Vasquez-Yanes C (eds) Physiological ecology of plants of the wet tropics. Springer, The Netherlands, pp 5184

Guo D, Xia M, Wei X, Chang W, Liu Y, Wang Z (2008) Anatomical traits associated with absorption and mycorrhizal colonization are linked to root branch order in twenty-three Chinese temperate tree species. New Phytol 180:673-683

Hertel D, Leuschner C, Hölscher D (2003) Size and strucutre of fine root systems in old-growth and secondary tropical montane forests (Costa Rica). Biotropica 35:143-153

Hodge A, Berta G, Doussan C, Merchan F, Crespi M (2009) Plant root growth architecture and function. Plant Soil 321:153-187

Hogan JA, Baraloto C, Valverde-Barrantes O, Xu H, Ding Q (2019) Sapling leaf and root traits from $6.6 \mathrm{~km}$ Jianfengling transect. Figshare repository. [Dataset]. V3. https://doi.org/10.6084/m9. figshare.7996328.v3

Holdaway RJ, Richardson SJ, Dickie IA, Peltzer DA, Coomes DA (2011) Species- and community-level patterns of fine root traits along a 120000-year soil chronosequence in temperate rainforest. J Ecol 99:954-963

Hopkins MS, Redell P, Hewett RK, Graham AW (1996) Comparison of root and mycorrhizal characterstics in primary and secondary forests on a metamorphoic soil in North Queensland, Australia. J Trop Ecol 12:871-885

Huang Q, Li Y, Zheng D, Zhang J, Wan L, Jiang Y, Zhao Y (1995) Study on tropical vegetation series in Jianfengling Hainan Island. In: Zeng Q, Zhou G, Yide L, Wu Z, Chen B (eds) Researches on tropical forest ecosystems in Jianfengling of China. China Forestry Publishing House, Beijing China, pp 5-25

Iversen CM, McCormack ML, Powell AS, Blackwood CB, Freschet GT, Kattge J, Roumet C, Stover DB, Soudzilovskaia NA, ValverdeBarrantes OJ (2017) A global Fine-Root Ecology Database to address below-ground challenges in plant ecology. New Phytol 215: $15-26$
Jackson R, Canadell J, Ehleringer JR, Mooney H, Sala O, Schulze E (1996) A global analysis of root distributions for terrestrial biomes. Oecologia 108:389-411

Jin D, Cao X, Ma K (2013) Leaf functional traits vary with the adult height of plant species in forest communities. J Plant Ecol 7:68-76

Keddy P (1992) A pragmatic approach to functional ecology. Funct Ecol 6:621-626

Keenan TF, Niinemets Ü (2017) Global leaf trait estimates biased due to plasticity in the shade. Nat Plants 3:16201

Kembel SW, Cahill JF Jr (2011) Independent evolution of leaf and root triats within and aming temperate grassland plant communities. PLoS One 6:e19992

King DA (1996) Allometry and life history of tropical trees. J Trop Ecol 12:25-44

Kong D, Ma C, Zhang Q, Li L, Chen X, Zeng H, Guo D (2014) Leading dimensions in absorptive root trait variation across 96 subtropical forest species. New Phytol 203:863-872

Kong D, Wang J, Zeng H, Liu M, Miao Y, Wu H, Kardol P (2017) The nutrient absorption-transportation hypothesis: optimizing structural traits in absorptive roots. New Phytol 213:1569-1572

Körner C (2018) Concepts in empirical plant ecology. Plant Ecol Divers 11:405-428

Kramer-Walter KR, Bellingham PJ, Smissen RD MTR, Richardson SJ, Laughlin DC (2016) Root traits are multidimensional: specific root length is independent from root tissue density and the plant economic spectrum. J Ecol 104:1299-1310

Laliberté E (2017) Below-ground frontiers in trait-based plant ecology. New Phytol 213:1597-1603

Laliberté E, Lambers H, Burgess TI, Wright SJ (2015) Phosphorus limitation soil-borne pathogens and the coexistence of plant species in hyperdiverse forests and shrublands. New Phytol 206:507-521

Lambers H, Shane MW, Cramer MD, Pearse SJ, Veneklaas EJ (2006) Root structure and functioning for efficient acquisition of phosphorus: matching morphological and physiological traits. Ann Bot 98: 693-713

Lambers H, Albornoz F, Kotula L, Laliberté E, Ranathunge K, Teste FP, Zemunik G (2017) How belowground interactions contribute to the coexistence of mycorrhizal and non-mycorrhizal species in severely phosphorus-impoverished hyperdiverse ecosystems. Plant Soil 424: $1-23$

Lenth R. (2018) Emmeans: estimated marginal means aka least-squares means R Package Version 1. https://CRAN.R-project.org/package $=$ emmeans

Leuschner C, Harteveld M, Hertel D (2009) Consequences of increasing forest use intensity for biomass, morphology and growth of fine roots in a tropical moist forest on Sulawesi, Indonesia. Agric Ecosyst Environ 129:474-481

Li F, Hu H, McCormack ML, Feng DF, Liu X, Bao W (2018) Community-level economics spectrum of fine roots driven by nutrient limitations in subalpine forests. J Ecol 107:1238-1249

Liu Y, Dawson W, Prati D, Haeuser E, Feng Y, van Kluenen M (2016) Does greater specific leaf area plasticity help plants maintain a high performance when shaded? Ann Bot 118:1329-1336

López-Bucio J, Cruz-Ramırez A, Herrera-Estrella L (2003) The role of nutrient availability in regulating root architecture. Curr Opin Plant Biol 6:280-287

Lu M, Hedin LO (2019) Global plant-symbiont organization and emergence of biogeochemical cycles resolved by evolution-based trait modeling. Nat Ecol Evol 3:239-250

Lüdecke D. (2019) sjstats: statistical function for regression models (version 0.17.3). R packge: https://www.cran.r-project.org/package= sjstats. https://doi.org/10.5281/zenodo.1284472

Lynch J (2005) Root architecture and nutrient acquisition. In: BassiriRad $\mathrm{H}$ (ed) Nutrient acquisition by plants (analysis and synthesis), vol 181. Springer, Berlin, pp 147-183 
Ma Z, Guo D, Xu X, Lu M, Bardgett RD, Eissenstat DM, McCormack ML, Hedin LO (2018) Evolutionary history resolves global organization of root functional traits. Nature 555:94-97

Maherali H (2017) The evolutionary ecology of roots. New Phytol 215: $1295-1297$

McCormack ML, Iversen CM (2019) Physical and functional constraints on viable belowground acquisition strategies. Front Plant Sci 10: 1215

McCormack ML, Adams TS, Smithwick EA, Eissenstat DM (2012) Predicting fine root lifespan from plant functional traits in temperate trees. New Phytol 195:823-831

McCormack ML, Dickie IA, Eissenstat DM, Fahey TJ, Fernandez CW, Guo D, Helmisaari HS, Iversen CM HEA, Jackson RB (2015) Redefining fine roots improves understanding of below-ground contributions to terrestrial biosphere processes. New Phytol 207:505518

Mommer L, Weemstra M (2012) The role of roots in the resource economics spectrum. New Phytol 195:725-727

Niu YF, Chai RS, Jin GL, Wang H, Tang CX, Zhang YS (2013) Responses of root architecture development to low phosphorus availability: a review. Ann Bot 112:391-408

Ostonen I, Püttsepp Ü, Biel C, Alberton O, Bakker M, Lõhmus K, Majdi H, Metcalfe D, Olsthoorn A, Pronk A (2007) Specific root length as an indicator of environmental change. Plant Biosyst 141:426-442

Parish JAD, Bazzaz FA (1976) Underground niche separation in succesional plants. Ecology 57:1281-1288

Phillips RP, Brzostek E, Midgley MG (2013) The mycorrhizal-associated nutrient economy: a new framework for predicting carbon-nutrient couplings in temperate forests. New Phytol 199:41-51

Powers JS, Peréz-Aviles D (2013) Edaphic factors are a more important control on surface roots than stand age in secondary tropical dry forests. Biotropica 45:1-9

Qui J (2008) Relationship between tropical forest canopy structure, understory vegetation and soil organic carbon content in Jianfengling, Hainan Island. Master's Thesis. Chinese Academy of Foresty. https://doi.org/10.7666/d.D602796

R Core Team. (2018) R: a language and environment for statistical computing. R Foundation for Statistical Computing Vienna Austria

Reich PB (2014) The world-wide 'fast-slow' plant economics spectrum: a traits manifesto. J Ecol 102:275-301

Rijkers T, Pons T, Bongers F (2000) The effect of tree height and light availability on photosynthetic leaf traits of four neotropical species differing in shade tolerance. Funct Ecol 14:77-86

Rosling A, Midgley MG, Cheeke T, Urbina H, Fransson P, Phillips RP (2016) Phosphorus cycling in deciduous forest soil differs between stands dominated by ecto-and arbuscular mycorrhizal trees. New Phytol 209:1184-1195

Schenk HJ, Jackson RB (2002) Rooting depths lateral root spreads and below-ground/above-ground allometries of plants in water-limited ecosystems. J Ecol 90:480-494

Shipley B. (1995) Structured interspecific determinants of specific leaf area in 34 species of herbaceous angiosperms. Funct Ecol 312-319

Shipley B, De Bello F, Cornelissen JHC, Laliberté E, Laughlin DC, Reich PB (2016) Reinforcing loose foundation stones in trait-based plant ecology. Oecologia 180:923-931

Turner BL (2008) Resource partitioning for soil phosphorus: a hypothesis. J Ecol 96:698-702

Turner BL, Brenes-Arguedas T, Condit R (2018) Pervasive phosphorus limitation of tree species but not communities in tropical forests. Nature 555:367-370

Ushio M, Fujiki Y, Hidaka A, Kitayama K (2015) Linkage of root physiology and morphology as an adaptation to soil phosphorus impoverishment in tropical montane forests. Funct Ecol 29:1235-1245

Valverde-Barrantes OJ, Blackwood CB (2016) Root traits are multidimensional: specific root length is independent from root tissue density and the plant economic spectrum: commentary on KramerWalter et al. (2016). J Ecol 104:1311-1313

Valverde-Barrantes OJ, Horning AL, Smemo KA, Blackwood CB (2016) Phylogenetically structured traits in root systems influence arbuscular mycorrhizal colonization in woody angiosperms. Plant Soil 404:1-12

Valverde-Barrantes OJ, Freschet GT, Roumet C, Blackwood CB (2017) A worldview of root traits: the influence of ancestry growth form climate and mycorrhizal association on the functional trait variation of fine-root tissues in seed plants. New Phytol 215:1562-1573

Van Kleunen M, Weber E, Fischer M (2010) A meta-analysis of trait differences between invasive and non-invasive plant species. Ecol Lett 13:235-245

Wang R, Wang Q, Zhao N, Yu G, He N (2017) Complex trait relationships between leaves and absorptive roots: coordiunation in tissue $\mathrm{N}$ concentration but divergence in morphology. Ecol Evol 7:26972705

Wang R, Wang Q, Zhao N, Xu Z, Zhu X, Jiao C, Yu G, He N (2018) Different phylogenetic and environmental controls of first-order root morphological and nutrient traits: evidence of multidimensional root traits. Funct Ecol 32:29-39

Wang C, McCormack ML, Guo D, Li J (2019) Global meta-analysis reveals different patterns of root tip adjustments by angiosperm and gymnosperm trees in response to environmental gradients. J Biogeogr 46:123-133

Warren JM, Hanson PJ, Iversen CM, Kumar J, Walker AP, Wullschleger SD (2015) Root structural and functional dynamics in bioshpere models - evaluation and recommendations. New Phytol 205:59-78

Weemstra M, Mommer L, Visser EJ, Ruijven J, Kuyper TW, Mohren GM, Sterck FJ (2016) Towards a multidimensional root trait framework: a tree root review. New Phytol 211:1159-1169

Weiher E, Werf A, Thompson K, Roderick M, Garnier E, Eriksson O (1999) Challenging Theophrastus: a common core list of plant traits for functional ecology. J Veg Sci 10:609-620

Wenhua L (2004) Degradation and restoration of forest ecosystems in China. For Ecol Manag 201:33-41

Werner P (1984) Changes in soil properties with wet forest succession in Costa Rica. Biotropica 16:43-50

Westoby M, Wright IJ (2006) Land-plant ecology on the basis of functional traits. Trends Ecol Evol 21:261-268

Wright IJ, Reich PB, Westoby M, Ackerly DD, Baruch Z, Bongers F, Cavender-Bares J, Chapin ST, Cornelissen JH, Diemer M (2004) The worldwide leaf economics spectrum. Nature 428:821-827

Wright SJ, Kitajima K, Kraft NJ, Reich PB, Wright IJ, Bunker DE, Condit R, Dalling JW, Davies SJ, Diaz S (2010) Functional traits and the growth-mortality trade-off in tropical trees. Ecology 91: 3664-3674

Wright IJ, Dong N, Maire V, Prentice IC, Westoby M, Díaz S, Gallagher RV, Jacobs BF, Kooyman R, Law EA, Leishman MR (2017) Global climatic drivers of leaf size. Science. 357(6354):917-921

Wu Z (1995) An introduction to the tropical forest soils and effect of shifting cultivation on soils in Jianfengling Hainan Island. In: Zeng Q, Zhou G, Yide L, Wu Z, Chen B (eds) Researches on tropical forest ecosystems in Jianfengling of China. China Forestry Publishing House, Beijing, pp 5-25

Xu H, Li Y, Liu S, Zang R, He F, Spence JR (2015) Partial recovery of a tropical rain forest a half-century after clear-cut and selective logging. J Appl Ecol 52:1044-1052

Zadworny M, McCormack ML, Mucha J, Reich PB, Oleksyn J (2016) Scots pine fine roots adjust along a $2000-\mathrm{km}$ latitudinal climatic gradient. New Phytol 212:389-399

Zangaro W, Alves RA, Lescano LE, Ansanelo AP (2012) Investment in fine roots and arbuscular mycorrhizal fungi decrease during succession in three Brazilian ecosystems. Biotropica 44:141-151 
Zemunik G, Turner BL, Lambers H, Laliberté E (2015) Diversity of plant nutrient-acquisition strategies increases during long-term ecosystem development. Nat Plants 1:15050

Zeng Q (1995) Survey of water-heat condition and vegetation ecological series in Jianfengling. In: Zeng Q, Zhou G, Yide L, Wu Z, Chen B (eds) Researches on tropical forest ecosystems in Jianfengling of China. China Forestry Publishing House, Beijing China, pp 5-25

Zhou G (1995) Ecological effects of human activities in Jianfenglin Forest Region Hainan Island. In: Zeng Q, Zhou G, Yide L, Wu Z,
Chen B (eds) Researches on tropical forest ecosystems in Jianfengling of China. China Forestry Publishing House, Beijing China, pp 38-48

Zhu H (2017) A biogeographical study on the flora of southern China. Ecol Evol 7:10398-10408

Publisher's note Springer Nature remains neutral with regard to jurisdictional claims in published maps and institutional affiliations. 